\title{
Insights on high-grade deformation in quartzo-feldspathic gneisses during the early Variscan exhumation of the Cabo Ortegal nappe, NW Iberia
}

\author{
Francisco José Fernández ${ }^{1}$, Sergio Llana-Fúnez ${ }^{1}$, Pablo Valverde-Vaquero ${ }^{2}$, Alberto Marcos ${ }^{1}$, and Pedro Castiñeiras ${ }^{3}$ \\ ${ }^{1}$ Departamento de Geología, Universidad de Oviedo, Jesús Arias de Velasco s/n, 33005 Oviedo, Spain \\ ${ }^{2}$ Área de Laboratorios, Instituto Geológico y Minero de España, La Calera 1, 28760 Tres Cantos, Spain \\ ${ }^{3}$ Departamento de Petrología y Geoquímica, Universidad Complutense de Madrid, José Antonio Novais 12,28040 Madrid, \\ Spain
}

Correspondence to: Francisco José Fernández (brojos@geol.uniovi.es)

Received: 25 November 2015 - Published in Solid Earth Discuss.: 7 December 2015

Revised: 21 March 2016 - Accepted: 22 March 2016 - Published: 13 April 2016

\begin{abstract}
High-grade, highly deformed gneisses crop out continuously along the Masanteo peninsula and constitute the upper part of the lower crustal section in the Cabo Ortegal nappe (NW Spain). The rock sequence formed by migmatitic quartzo-feldspathic (qz-fsp) gneisses and mafic rocks records the early Ordovician (ca. 480-488 Ma) injection of felsic dioritic/granodioritic dykes at the base of the qz-fsp gneisses, and Devonian eclogitization (ca. 390.4 $\pm 1.2 \mathrm{Ma}$ ), prior to its exhumation. A SE-vergent ductile thrust constitutes the base of quartzo-feldspathic gneissic unit, incorporating mafic eclogite blocks within migmatitic gneisses. A NW-vergent detachment displaced metasedimentary qz-fsp gneisses over the migmatites. A difference in metamorphic pressure of ca. $0.5 \mathrm{GPa}$ is estimated between both gneissic units. The tectono-metamorphic relationships of the basal ductile thrust and the normal detachment bounding the top of the migmatites indicate that both discrete mechanical contacts were active before the recumbent folding affecting the sequence of gneisses during their final emplacement. The progressive tectonic exhumation from eclogite to greenschist facies conditions occurred over ca. $10 \mathrm{Ma}$ and involved bulk thinning of the high-grade rock sequence in the high pressure and high temperature (HP-HT) Cabo Ortegal nappe. The necessary strain was accommodated by the development of a widespread main foliation, dominated by flattening, that subsequently localized to a network of anastomosing shear bands that evolved to planar shear zones. Qz-fsp gneisses and neighbouring mafic granulites were exhumed at
\end{abstract}

$>3 \mathrm{~mm} \mathrm{yr}^{-1}$, and the exhumation path involved a cooling of $\sim 20^{\circ} \mathrm{C} / 100 \mathrm{MPa}$, These figures are comparable to currently active subduction zones, although exhumation $\mathrm{P}-\mathrm{T}$ trajectory and ascent rates are at the hotter and slower end in comparison with currently active similar settings, suggesting an extremely ductile deformation environment during the exhumation of qz-fsp gneisses within a coherent Cabo Ortegal nappe.

\section{Introduction}

The processes involved in the exhumation of high-pressure (HP) and ultra-high-pressure (UHP) rocks in subduction zones remain a hot topic in tectonics given the complexity of strain and displacement paths that rocks follow, from the surface to great depths and back to the surface (e.g. Gerya et al., 2008). The boundary interval between convergent plates concentrates a large amount of strain and also heterogeneity (e.g. Escher and Beaumont 1997). This interval in subduction zones, named as the subduction channel, is characterized by non-parallel planar rigid edges on either side, on a profile having a narrow, downward-tapering triangular shape (i.e. Bird, 1978; England and Holland, 1979; Shreve and Cloos, 1986; Mancktelow, 1995). Under this configuration, the convergence of rigid plates squeezing a non-compressible viscous material introduces a stress gradient in the system that leads to a non-lithostatic pressure gradient with depth (e.g. Mancktelow, 1995). If the shearing associated with the con- 
vergence is taken into account, the result is that particles close to the subducting plate will follow the lower boundary, but once they reach the vertex of the triangular channel will be entrained to return to the surface, following the upper rigid boundary (see Fig. 4 in Shreve and Cloos, 1986). In fact, the exhumation of high pressure rocks represents the return flow in the system, so that subduction zones need to be active in order that high pressure rocks may reach the surface. The rheology of rocks in the subduction channel has an impact that affects the velocity of exhumation in comparison to subduction rates. Exhumation rate is about $1 / 3$ of the subduction rate if deformation approaches a Newtonian behaviour; but is slower if deformation is dominated by more non-linear processes such as dislocation creep, becoming about $1 / 6$ of the subduction rate (Gerya and Stöckhert, 2002). In addition, there is substantial intrinsic heterogeneity in the system at the boundary between plates, which can be now be visualised in numerical models (e.g. Gerya et al., 2008; Burov et al., 2014a, b). The rock record does not always preserve all the deformation stages, thus the difficulty in inferring a finite strain/displacement pathway for rocks and rock units remains.

In continental collision, subsequent in most cases to a subduction stage, there are some analogies with the "subduction channel" or the boundary zone between plates, but some major differences. The first major difference is that, as a consequence of the less-rigid plate boundaries involved, the extent in cross-section of this idealized downward-tapering plate boundary increases substantially (e.g. Gerya et al., 2008). In the upper part it consists of an orogenic wedge, a Coulomb wedge or an accretionary wedge. It has a triangular shape in cross-section, but the angles between sides can vary. Displacement paths of particles within the system do follow the sides of this wedge, but the dynamics are completely different from the deeper domain. In orogenic wedges, the exhumation of subducted rocks from depths greater than $50 \mathrm{~km}$ cannot be satisfactorily explained by classical collision models, such as in the dynamics of accretionary wedges (i.e. Davis et al., 1983; Platt, 1986) or by exhumation by extensional collapse of the orogen (i.e. Chemenda et al., 1995). In fact, insights from numerical models of ultra-high-pressure (UHP) exhumation at the continental collisional phase are consistent with a multi-stage process, where exhumation seems to start after a degree of continental subduction for most continental collision zones (e.g. Burov et al., 2014a, b).

One aspect of significance associated with the dynamics of channel flow at a crustal scale in collisional orogens is the upward extrusion of high-grade rocks squeezed between colliding plates. In the case of the Himalayan-Tibet system, the great crustal thickness beneath the Tibetan Plateau contributes significantly to the lithostatic pressure gradient required to force the lateral and frontal flow of a ductile lower crust (e.g. Beaumont et al., 2004; Rutter et al., 2011). Highly sheared and migmatized rocks of the greater Himalayan sequence between the Main Central Thrust and the South Ti- betan Detachment are effectively extruded towards the foreland. The extrusion process involves substantial thinning of the slab or fragment of crust involved in the subduction or collision. This is also apparent from numerical models, where a weak accretionary wedge can be squeezed out between the mantle portions of both colliding plates (e.g. Gerya et al., 2008).

Relics of the plate boundary region between northern Gondwana and Laurasia, and the accretionary complex sandwiched in between, are preserved in the high-grade allochthonous complexes of NW Iberian peninsula (e.g. Ries and Shackleton, 1971; Martínez-Catalán et al., 1997; Matte, 2001). The timing, kinematics, and structure of one of these, the Cabo Ortegal complex (COC), has been discussed over the past 45 years, and many hypotheses and models have been proposed to explain the exhumation and final tectonic emplacement of the high-grade, high-pressure rocks that form the greater part of the COC as it is presently exposed. Initially the debate was focused on whether the Cabo Ortegal complex represents evidence of a mantle plume, as proposed by the Leiden group (e.g. van Calsteren et al., 1979) or was in fact an allochthonous thrust sheet, as supported by many other schools since then (e.g. Ries and Shackleton, 1971; Bayer and Matte, 1979). A second point of contention was whether high-pressure metamorphism and the sequence of structures represented a deep tectonic setting, i.e. the remains of the subduction channel itself (e.g. Ábalos et al., 2003), or were due to the superposition of structures during their exhumation from high-pressure conditions (e.g. Marcos et al., 2002). Regarding the initial exhumation from highpressure conditions to mid-crustal depths, several mechanisms have been proposed, in relation to extensional tectonics (e.g. Martínez-Catalán et al., 1997), ductile slab breakoff (e.g. Llana-Fúnez et al, 2004) or more recently channel flow (e.g. Albert et al., 2012).

The Masanteo peninsula (Figs. 1 and 2), located on the eastern side of the Cabo Ortegal Complex, offers a continuous exposure through the quartzo-feldspathic (qz-fsp) gneisses in the structurally upper part of the coherent rock sequence that constitutes the Cabo Ortegal nappe, the part of the COC that registers widespread high-pressure and hightemperature metamorphism which is also associated with generalized intense deformation. In this paper, we present a detailed structural analysis of the high-grade tectonic sequence at the contact between the eclogitic mafic gneisses and the qz-fsp gneisses, on the eastern side of the Cabo Ortegal nappe (Fig. 2a). These gneisses are quite exposed in clean exposures along the shores of the Masanteo peninsula, covering an area of $4.5 \mathrm{~km}^{2}$.

A detailed mapping of the gneisses and the reconstruction of the rock unit geometry on the basis of the attitude of the main tectonic foliation $\left(S_{2}\right)$ is therefore presented here with the aim of understanding the mechanism of deformation in the tectonized zone between mafic and quartzo-feldspathic rocks during the exhumation of subducted lower crust. The 


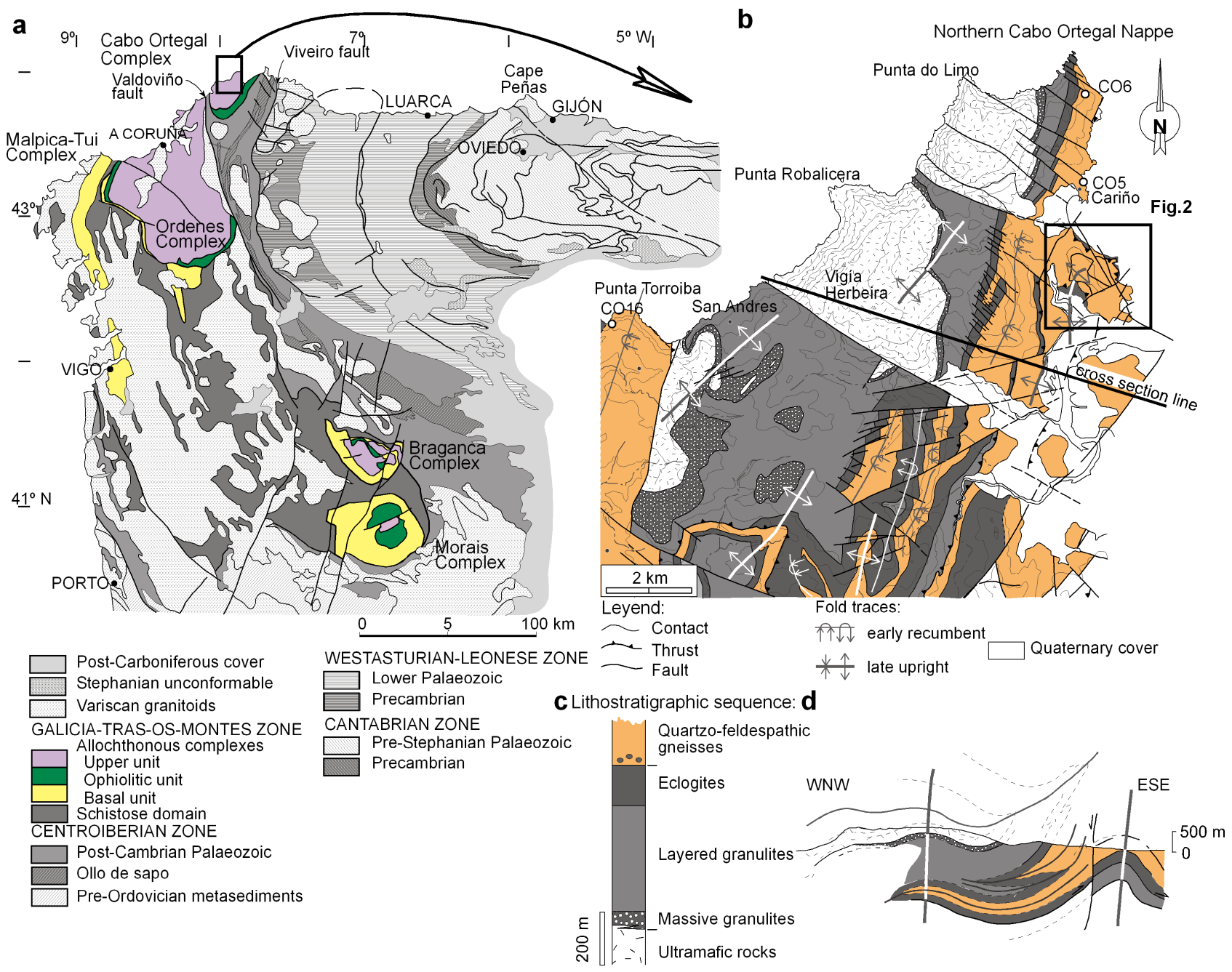

Figure 1. (a) Geological map of the Variscan Belt in N Iberia, highlighting the allochthonous complexes, based on Parga Pondal et al. (1982). (b) Geological map with location of Fig. 2 and the CPOs samples. (c) Lithostratigraphic sequence and (d) cross-section of Cabo Ortegal nappe (after Marcos et al., 2002).

deduction of the tectonic evolution in the gneisses is based on newly observed structural relationships, recent Uraniumlead $(\mathrm{U}-\mathrm{Pb})$ ages, and is supported by geothermobarometry data from previous studies in the gneisses and neighbouring mafic rock units. The insights from well-preserved high-grade structures observed in the field are believed to be the key to understanding the processes of orogenic collision and to constrain thermo-mechanical models. The integration of published geochronological data, metamorphic evolution and the structural development helps to constrain some characteristics of the process of exhumation of highgrade gneisses from eclogite conditions to greenschist facies. In this contribution, we provide robust figures for the bulk exhumation rate and amount of cooling during exhumation of high-pressure rocks in the Cabo Ortegal nappe which may be regarded as representative for a larger lower crustal section.

\section{The geological framework: the Cabo Ortegal complex}

High-grade relicts of continental collision overlie tectonically most of the hinterland of the Variscan orogeny in NW Iberia, forming a tectonic pile of oceanic and sedimentary material that can be recognized totally or partially within five allochthonous complexes (Martínez-Catalán et al., 1997). Three main units form this allochthonous tectonic pile. The upper unit includes ultramafic, mafic, and qz-fsp gneissic rocks that recorded high-pressure and high-temperature (HP-HT) metamorphism (e.g. Vogel, 1967). Rocks characteristic of distinct geodynamic settings, such as E-MORB basalts, tectonic melanges and arc volcanics (Arenas, 1986; Díaz-García et al., 1999; Pin et al., 2006; Arenas et al., 2007) form the intermediate ophiolitic unit. The basal unit is formed by metasediments intruded by acid and basic 


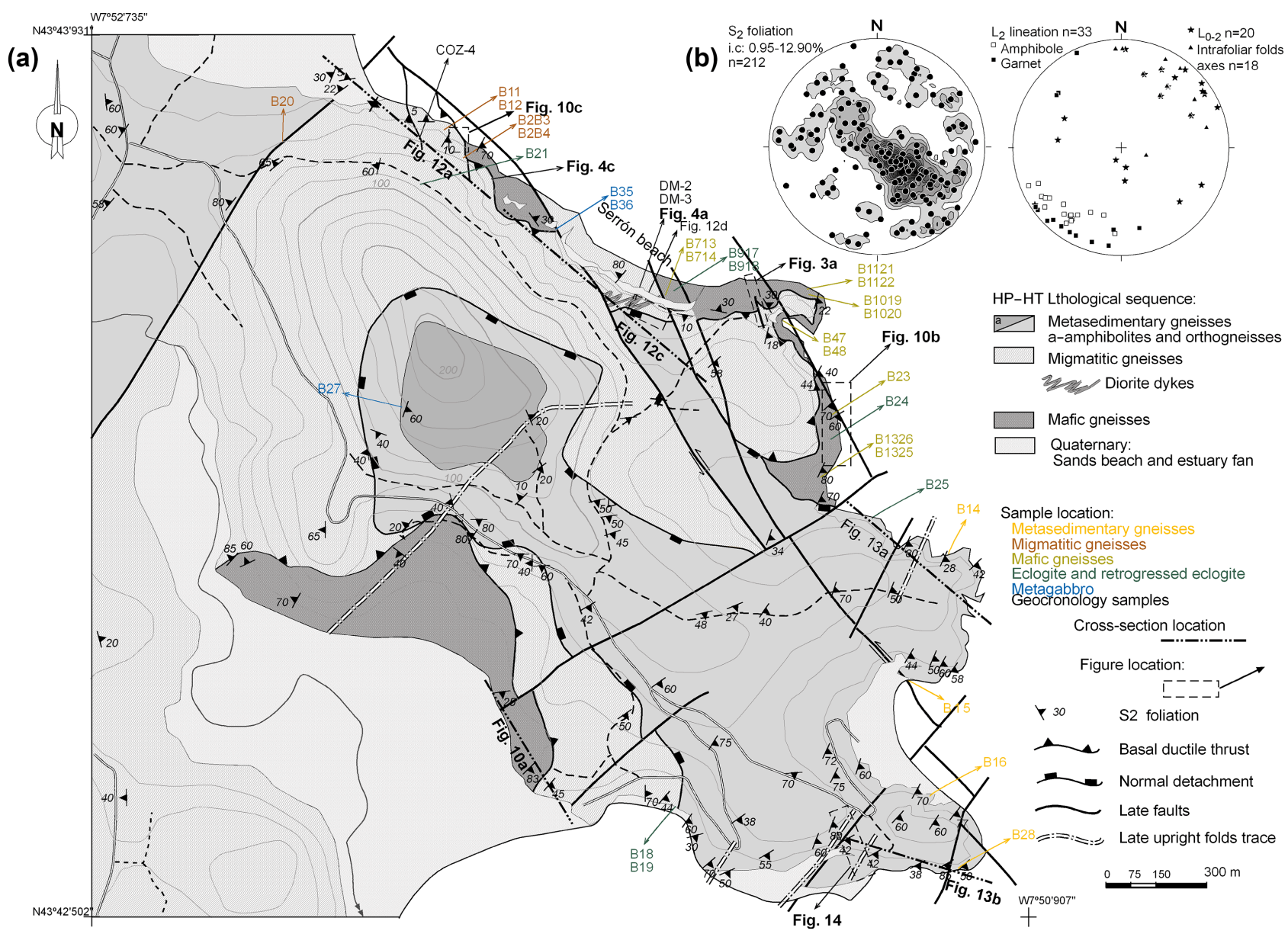

Figure 2. (a) Geological map of the Masanteo peninsula with location of samples, figures and cross-sections. Pole figures in (b) show the distribution of $S_{2}$-foliation poles and related structures (lineation and intrafolial fold axes). Equal area projection, lower hemisphere.

igneous rocks that recorded blueschist facies and low- to intermediate-temperature eclogite facies conditions (e.g. GilIbarguchi and Ortega-Girones, 1985; Arenas et al., 1995; López-Carmona et al., 2014).

The Cabo Ortegal complex is the northernmost of the allochthonous complexes, sitting on rocks of the Central Iberian Zone, and the closest to the foreland of the orogen (Fig. 1a; e.g. Pérez-Estaún et al., 1991). This complex is exposed along a coastal section with cliffs up to $600 \mathrm{~m}$ above sea-level, and contains some of the best exposures of HPHT rocks of the Variscan orogen. Internally, it is divided into two main tectonic units: the Cabo Ortegal nappe and the lower tectonic unit (Marcos et al., 2002). The Cabo Ortegal nappe (Fig. 1b) is composed of ultramafic rocks, mafic granulites, eclogites, and high-grade gneisses with HP-HT metamorphism, which are the objects of this study. The underlying lower tectonic unit is composed of three thrust sheets: the ophiolitic unit, the basal unit, and the para-autochthonous rock sequence (Marcos and Farias, 1999).

There are three major lithological units that form the highgrade Cabo Ortegal nappe (Vogel, 1967). From bottom to top, according to the lithostratigraphic column in Fig. 1c, the base is formed by $>600 \mathrm{~m}$ of mantle-derived ultramafic rocks, metaperidotites, and garnet pyroxenites (Girardeau et al., 1989), overlain by a $400 \mathrm{~m}$ thick layer of mafic HP granulites. The granulites are in sharp contact with a $100-200 \mathrm{~m}$ thick unit of massive, high-temperature eclogite derived from N-MORB mafic protoliths (e.g. Peucat et al., 1990). The eclogite unit is capped by quartzo-feldspathic gneisses (> $600 \mathrm{~m}$ thick), also described as HP gneisses by Ábalos et al. (2003). The qz-fsp gneisses along the contact with the eclogite unit contain decametric to metric scale lenses of mafic eclogite and locally show evidences of partial anatexis and migmatization (Vogel, 1967; Gil-Ibarguchi et al., 1990; Fernández, 1997). These migmatitic gneisses correspond to the Chimparra and banded gneisses of Vogel (1967). Metasedimentary, supracrustal, pelitic, and psammitic paragneisses overlie the migmatitic qz-fsp gneisses, and mark the top of the high-grade nappe. This higher paragneiss unit is the Cariño gneiss of Vogel (1967). It also displays evidence of HP metamorphism (Fig. 5) but indications of anatexis are scarce. These units are interpreted to outcrop largely in 
the shape of an early recumbent synform (Fig. 1d; Marcos et al., 2002). Overall, the whole lithostratigraphic sequence has been used as a proxy for the continental crust-mantle transition (Brown et al., 2009); and according to Ábalos et al. (2003), it represents a stack of crustal and mantle units assembled in a subduction channel, i.e. with oceanic origins; it could also represent a continental lower crustal/uppermost mantle sequence that has been partially subducted and exhumed.

\section{Tectonic evolution of the high-grade Cabo Ortegal nappe}

The high-pressure rocks of Cabo Ortegal are affected by several phases and stages of deformation and metamorphism. Protolith ages of the ultramafic and mafic rocks in the Cabo Ortegal nappe are considered Cambro-Ordovician on the basis of 520-490 Ma U-Pb zircon (Peucat et al., 1990; Ordoñez-Casado et al., 2001) and Samarium-Neodymium (Sr-Nd) ages (Santos et al., 2002). Fernández-Suárez et al. (2002) reported 480-490 Ma U-Pb monazite and zircon ages from anatectic pods in the mafic granulites and the migmatitic qz-fsp gneisses, suggesting the presence of a Cambro-Ordovician metamorphic overprint similar to that reported by Abati et al. (1999) from equivalent units in the neighbouring Órdenes complex (Fig. 1a).

An early-mid Devonian (400-388 Ma) HP-HT metamorphic event is well documented by Garnet-Clinopyroxene (Grt-Cpx) whole-rock Sm-Nd ages in the metaperidotites of the ultramafic unit (Santos et al., 2002), U-Pb zircon ages in the eclogite unit (e.g. Peucat et al., 1990; Santos-Zalduegui et al., 1996; Ordóñez-Casado et al., 2001) and zircon, monazite, and titanite $\mathrm{U}-\mathrm{Pb}$ ages from the mafic granulite and the qz-fsp gneisses (Santos-Zalduegui et al., 1996; Fernández-Suárez et al., 2002, 2007). This event reached metamorphic conditions above $800^{\circ} \mathrm{C}$ and $1.7 \mathrm{GPa}$ (Gil-Ibarguchi et al., 1990; Fernández, 1997; Galán and Marcos, 2000). The eclogitic and granulitic rocks registered partial anatexis during the initiation of decompression at peak temperature conditions, which was followed by partial retrogression and amphibolitization. Cooling ages in amphibole (390-380 Ma), rutile (U-Pb, ca. 383 Ma; Santos-Zalduegui et al., 1996; Valverde-Vaquero and Fernandez, 1996) and muscovite (375 Ma; Argon-Argon (Ar-Ar) data, Peucat et al., 1990) ages indicate a fast cooling and rapid exhumation of the HP-HT rocks that constitute the nappe following peak HP conditions (see Ordoñez Casado et al., 2001).

The development of structures associated with metamorphism allow the definition of a relative chronology made of locally four deformation events in the Cabo Ortegal nappe. It should be noted that these phases that do not have a direct correlation with the three main regional deformation phases in the underlying, autochthonous rock sequence (e.g. PérezEstaún et al., 1991). Some authors interpret inclusion trails as representing a distinct earliest event ( $D_{1}$ structures) formed during the prograde path related to the subduction stage (i.e.
Ábalos et al., 2003); even though only the fabric elements of the retrograde Pressure-Temperature-time $(\mathrm{P}-\mathrm{T}-\mathrm{t})$ path have been unequivocally recognized (Gil-Ibarguchi et al., 1990; Fernández, 1997; Galán and Marcos, 2000). All units of the high-grade nappe show a pervasive blastomylonitic tectonic fabric, which locally is highly heterogeneously developed (Fernández, 1997; Marcos et al, 2002). This main tectonic fabric and associated structures define a regionally recognizable deformation episode (labelled $D_{2}$ ), formed during the exhumation from high-pressure conditions. Frequently, the blastomylonitic foliation $\left(S_{2}\right)$ forms networks of anastomosed shear zones, and defines lozenge-shaped bodies of layered migmatitic gneisses that preserve even earlierdeveloped fabrics (Fernández and Marcos, 1996). Whilst there is a lack of a pervasively developed mineral lineation, the symmetry of quartz crystallographic preferred orientation (CPO) patterns suggests a predominantly coaxial deformation during fabric development in the gneisses (Fernández, 1997). The omphacite CPO fabrics in neighbouring eclogite units show a similar pattern, also consistent with flattening strain in the plane of foliation (Llana-Fúnez et al., 2005). Overall, bulk coaxial strain dominated the $D_{2}$ deformation and controlled the bulk tectonic thinning of the rock sequence in the Cabo Ortegal nappe (Llana-Fúnez et al, 2004).

Large-scale recumbent folding resulted in the inversion of the lithostratigraphy along a reverse limb for more than $6 \mathrm{~km}$ in the direction of tectonic transport, and determines the overall outcrop pattern in the COC. This folding deforms the $D_{2}$ fabric and is hence recognized as $D_{3}$.

Later asymmetric folds of decametric size cut across $D_{2}$ folds and mark the formation of a large E-verging recumbent $D_{3}$-fold, which was overprinted by two major thrusts attributed to $D_{4}$ (Fig. 1 b and d; Marcos et al., 1984, 2002). The subsequent tectonic evolution was controlled by the progressive localization of strain and the deformation along thrusts and the final emplacement of the HP-HT Cabo Ortegal nappe.

The $D_{4 a}$-thrusts imbricated the Cabo Ortegal nappe as part of its progressive emplacement toward the ESE over the underlying ophiolitic rock units (Marcos and Farias, 1999). This presumably implies that the emplacement over the ophiolitic rocks was now under greenschist facies conditions. Late $D_{4 \mathrm{~b}}$-upright refolding produced the elliptical final shape of the Cabo Ortegal synformal complex that led to its preservation from erosion. The other allochthonous complexes were similarly affected, and upright large-scale folds of similar orientation also affect the rocks of the underlying autochthon during the later part of the Variscan Orogeny (Matte, 1968; Marcos, 1971; Pérez-Estaún et al., 1991). The kilometric amplitude and wavelength of upright folds reach crustal-scale and evidence continuing shortening subsequently to the emplacement of allochthonous complexes (Llana-Fúnez and Marcos, 2007). 


\section{The rock sequence at Masanteo peninsula}

The rock sequence that crops out in the Masanteo peninsula is more than $300 \mathrm{~m}$ thick. It is a high-grade imbricated section of the upper part of the mafic-banded gneisses and the qz-fsp, migmatitic, and metasedimentary gneisses (Fig. 2a). The whole sequence shows a heterogeneous deformation defined by a ductile pervasive $S_{2}$ foliation. Anastomosed and planar $D_{2}$ shear zones are widespread, and include metricsized boudins of eclogite, ultramafic, and mafic rocks. The anastomosing shear zones surround lozenge-shaped bodies within the layered migmatitic gneisses. The size of lozenges ranges from 0.5 to $4 \mathrm{~m}$. The $D_{2}$-shear zones also include symmetric- and rotational structures of centimetre-size and rootless-intrafolial folds. The $D_{2}$-planar tectonites do not show a consistently developed stretching lineation. However, the intersection between the $S_{2}$ foliation and the compositional or migmatitic layering forms locally a linear fabric. Also locally, the $D_{2}$ high-strain zones show garnet or amphibole lineations with scattered patterns (Fig. 2b). The mineral assemblages $\left(M_{2}\right)$ associated with this dominant $D_{2}$ deformation indicate retrogression from eclogite to amphibolite facies during the imbrication of the whole stack (Gil-Ibarguchi et al., 1990; Fernández, 1997; Mendia 2000). The following is a description of the main lithological units within the $D_{2}$ imbricate complex at the Masanteo peninsula.

\subsection{Mafic gneisses}

Highly strained amphibole-bearing gneisses crop out at the base of the Masanteo cliff (Fig. 3). These amphibolitic gneisses enclose boudins and blocks of eclogite, partly retrogressed eclogite, and rare metagabbros. The amphibolitic gneisses have a high-strain $D_{2}$ fabric defined by a mineral assemblage with $\mathrm{Qz}+\mathrm{Pl}+\mathrm{Hbl}+\mathrm{Ky}+\mathrm{Grt}$ $+\mathrm{Bt} \pm \mathrm{Kfs} \pm \mathrm{Czo} \pm \mathrm{Ilm} \pm \mathrm{Ttn}$ (mineral abbreviations following Whitney and Evans, 2010). The eclogite boudins are composed of Omp $+\mathrm{Grt} \pm \mathrm{Hbl}$, and often preserve undeformed textures with inclusions of Rt in Grt, and locally contain mesocratic melt pods. The mineral assemblage in the retrogressed eclogites is formed by $\mathrm{Qz}+\mathrm{Grt}+$ $\mathrm{Omp} \pm \mathrm{Hbl} \pm \mathrm{Bt} \pm \mathrm{Pl} \pm \mathrm{Rt} \pm \mathrm{Ilm} \pm \mathrm{Ttn}$. The rare metagabbros $(\mathrm{Ol}+\mathrm{Pl}+\mathrm{Grt} \pm \mathrm{Ab} \pm \mathrm{Ep})$ preserve relict ophitic textures and prograde pre-eclogitization coronitic garnets. This $D_{2}$ fabric developed in both mafic and migmatitic gneisses and characterizes such contacts. Peak metamorphic conditions during the eclogite stage have been constrained by Mendia (2000) at $800^{\circ} \mathrm{C}$ and $2.2 \mathrm{GPa}$.

\subsection{Migmatitic gneisses}

These migmatitic gneisses correspond to the "bandedgneisses" of Vogel (1967) and are equivalent to his Chimparra gneiss. They are the highest grade qz-fsp gneisses in the Cabo Ortegal nappe. They consist of $\mathrm{Ky} \pm \mathrm{Rt} \pm$ Grt-
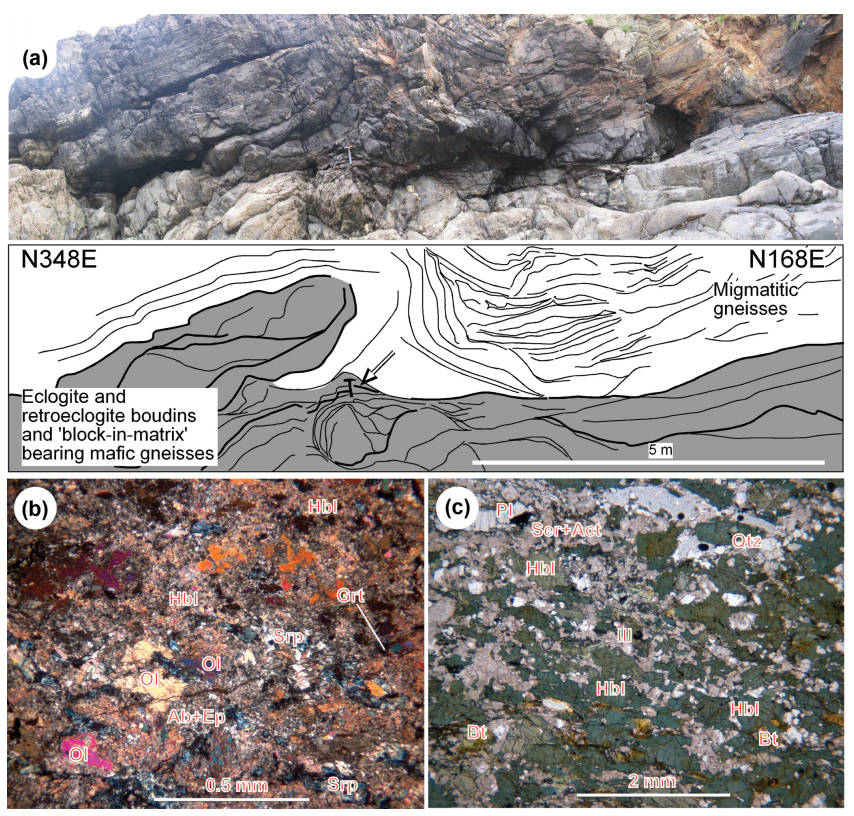

Figure 3. Mafic gneisses and related rocks. (a) Structures at the exposure scale; the sketch shows the attitude of the main $S_{2}$ foliation at the contact between mafic gneisses and migmatitic gneisses. Microphotographs: (b) retrogressed coronitic metagabbro (sample B917); (c) Bt-Grt-bearing amphibolite gneisses within the less deformed lozenges (sample B714). Sample location is indicated in Fig. 2a.

bearing layered, biotite-rich migmatites. At the Masanteo peninsula they are sandwiched between the mafic gneisses and the overlying metasedimentary gneisses. Locally, they contain centimetric to decimetric thick bands of orthogneiss $(\mathrm{Qz}+\mathrm{Mc}+\mathrm{Pl}+\mathrm{Grt}+\mathrm{Ms}+\mathrm{Bt})$ intruded by felsic $(\mathrm{Qz}$ $+\mathrm{Pl}+\mathrm{Kfs}+\mathrm{Grt}+\mathrm{Hbl} \pm \mathrm{Czo}$ ) and tonalitic/granodioritic dykes intercalated in the migmatitic gneisses. The total thickness of this gneissic unit ranges from 50 to $200 \mathrm{~m}$. The migmatitic gneisses have two compositional end-members: a melanosome-dominated, biotitic qz-fsp gneiss (Fig. 4d) with $\mathrm{Ky}+\mathrm{Grt}+\mathrm{Bt} \pm \mathrm{Hbl} \pm \mathrm{Czo} \pm \mathrm{Ilm} \pm \mathrm{Ttn}$, with less than $20 \%$ of leucosome; and a banded leucocratic qz-fsp gneisses (Fig. 4f) with $\mathrm{Qz}+\mathrm{Pl}+\mathrm{Kfs} \pm \mathrm{Ky} \pm \mathrm{CzO} \pm \mathrm{Ilm} \pm \mathrm{Ttn}$ with less than $20 \%$ of melanosome. The difference in modal composition may relate to differences in the primary composition of the metasedimentary rocks; however, compositional differentiation may also be a consequence of migmatization and/or subsequent deformation. The banded leucocratic gneisses are located on the upper section of the migmatitic unit, while the biotite-rich migmatitic gneiss occurs along the contact with the underlying mafic gneiss. A phyllonitic fabric of the biotite gneisses, including centimetric layers of restitic material (Fig. 4e), and its location overlying the mafic gneisses points to deformation in high-grade conditions.

Peak metamorphic conditions estimated for the migmatitic gneisses in the Masanteo peninsula have been estimated 

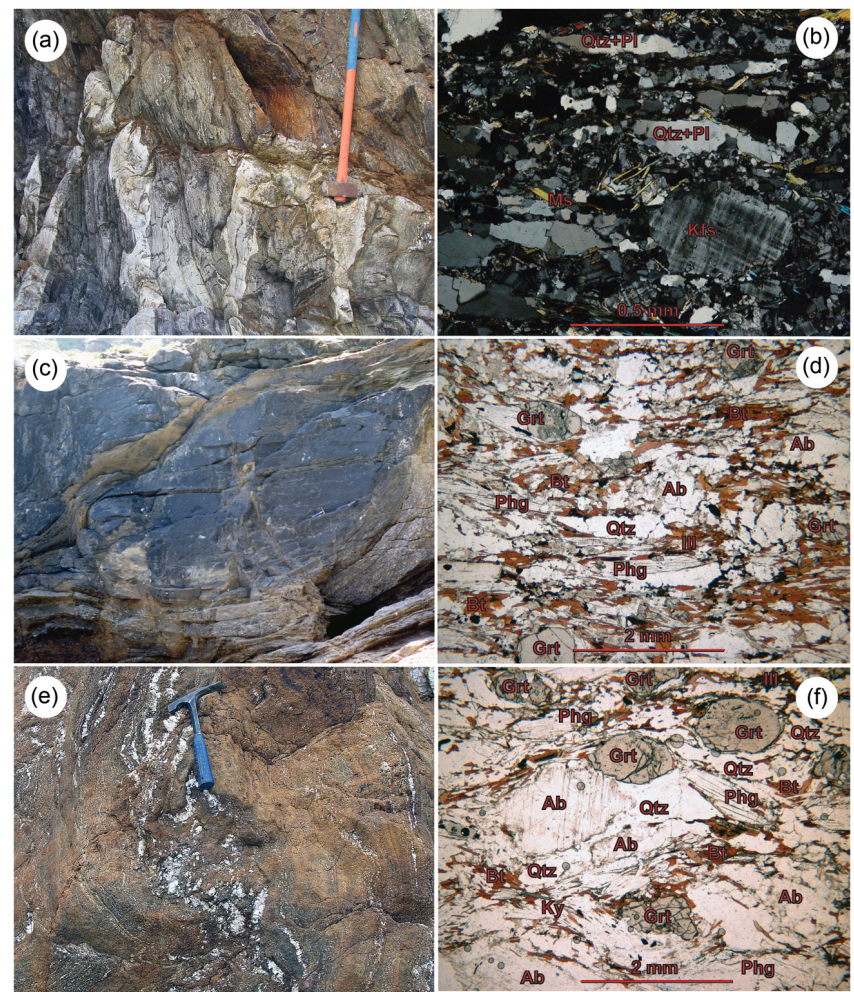

Figure 4. Migmatitic biotite qz-fsp gneisses and related rocks. (a) Folding affecting a felsic dioritic dyke and the $S_{2}$ foliation. (b) Microphotograph of the felsic diorite dyke showing a coarse foliation (sample DM-2). (c) Anastomosing shear zones defined by the $S_{2}$ foliation surrounding lozenges of less deformed migmatitic qz-fsp gneisses. (d) Microphotograph of the biotite qz-fsp gneisses (sample B23). (e) Restite in migmatitic qz-fsp gneisses. (f) Microphotograph of the leucocratic qz-fsp gneisses (sample B12). Sample locations are in Fig. 2a.

at $720^{\circ} \mathrm{C}$ and $1.5 \mathrm{GPa}$ (Gil-Ibarguchi et al, 1990). Estimates of metamorphic conditions of equivalent biotite qz-fsp gneisses in Punta Tarroiba (location in Fig. 1b), the Chimparra gneisses (Vogel, 1967), show slightly higher values of $800^{\circ} \mathrm{C}$ and $1.7 \mathrm{GPa}$ (Fernández, 1997) comparable to conditions calculated in the eclogites (Fig. 5).

Locally, the structural relationships between the blastomylonitic $S_{2}$ foliation and felsic dioritic/granodioritic dykes allow the relative timing of events in these gneisses to be constrained. The felsic dykes are buckled by metric folds that are transected by the $S_{2}$ foliation (Fig. 4a and b), demonstrate that intrusion and folding of the felsic dykes occurred before the $D_{2}$ deformation. The $S_{2}$ foliation shows sub-parallelism with the migmatitic layering and bounds concordantly the eclogite blocks (Fig. 4c). Castiñeiras et al. (2010) sampled one of these eclogitic boudins (sample COZ-4; Fig. 2) and obtained a U-Pb zircon age of $390 \pm 2 \mathrm{Ma}$. The field relationships suggest that local anatexis and migmatization must have occurred during the early stages of $D_{2}$, after eclogitization. Thus, the migmatitic qz-fsp gneisses appar-

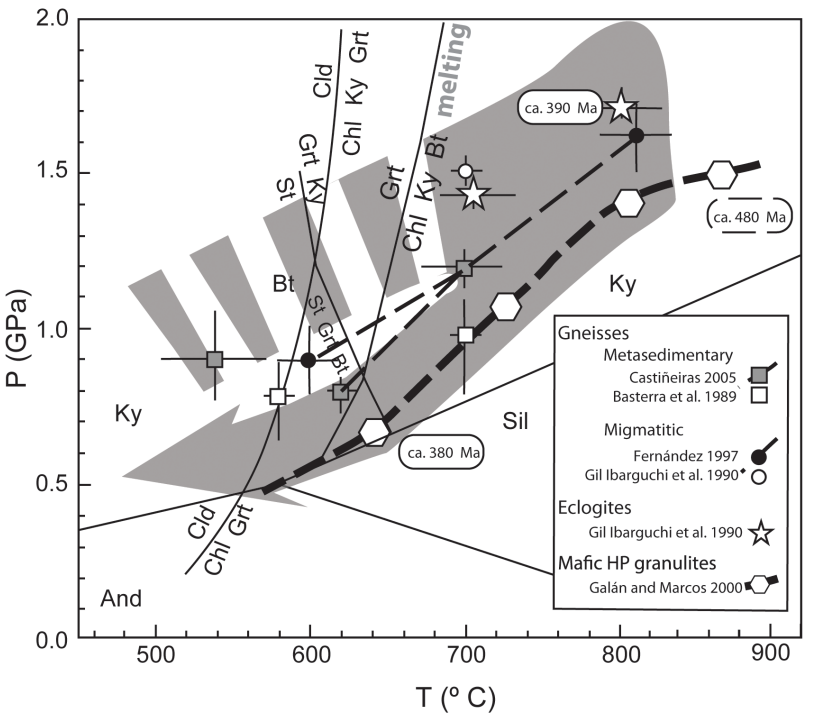

Figure 5. P-T data calculated for metasedimentary and migmatitic qz-fsp gneisses in Cabo Ortegal nappe, based on the available published data, indicated in the legend. $\mathrm{Al}_{2} \mathrm{SiO}_{5}$ phase diagram after Holdaway (1971). Error bars are also plotted. P-T path in the gneisses proposed is in grey. Detailed metamorphic work by Galán and Marcos (2000) traced the P-T-t path (thick dashed line) of the underlying Mafic granulites (after Galán and Marcos, 2000) is also plotted. Thin dashed lines trace sub-parallel retrograde paths for metasedimentary and migmatitic qz-fsp gneisses

ently have recorded an early intrusive event related to the injection of the pre- $D_{2}$ dioritic/granodioritic dykes in the gneisses, and a latter anatectic melting event that produced the migmatitic layering, which is preserved within the less deformed lozenges bodies surrounded by anastomosing $D_{2}$ shear bands.

\section{New U-Pb ID-TIMS geochronology in the migmatitic gneiss}

In order to constrain the ages of pre- $D_{2}$ felsic dykes, two separate felsic dykes (DM-2 and DM-3; Fig. 4a, b) were dated by U-Pb ID-TIMS at the IGME geochronology laboratory in Tres Cantos (Spain). Zircon and monazite were analysed following the procedures outlined in Rubio Ordoñez et al. (2012). The zircon fractions were chemically abraded before final dissolution.

In the case of sample DM-2, two zircon and three monazite fractions were analysed (Table 1; Fig. 6). The zircon fractions are discordant, while the three monazite fractions overlap the concordia curve, providing concordant ages at $475\left(M_{1}\right), 478$ $\left(M_{2}\right)$ and $485 \mathrm{Ma}\left(M_{3}\right)$. These three monazite fractions are colinear and provide a lower intercept age of $384 \pm 180 \mathrm{Ma}$ and an upper intercept age of $479 \pm 6.5 \mathrm{Ma}$. For sample DM3 , four zircon and three monazite fractions were dated (Table 1; Fig. 6). The monazite and zircon fractions $\mathrm{Z1}, \mathrm{Z4}$, 

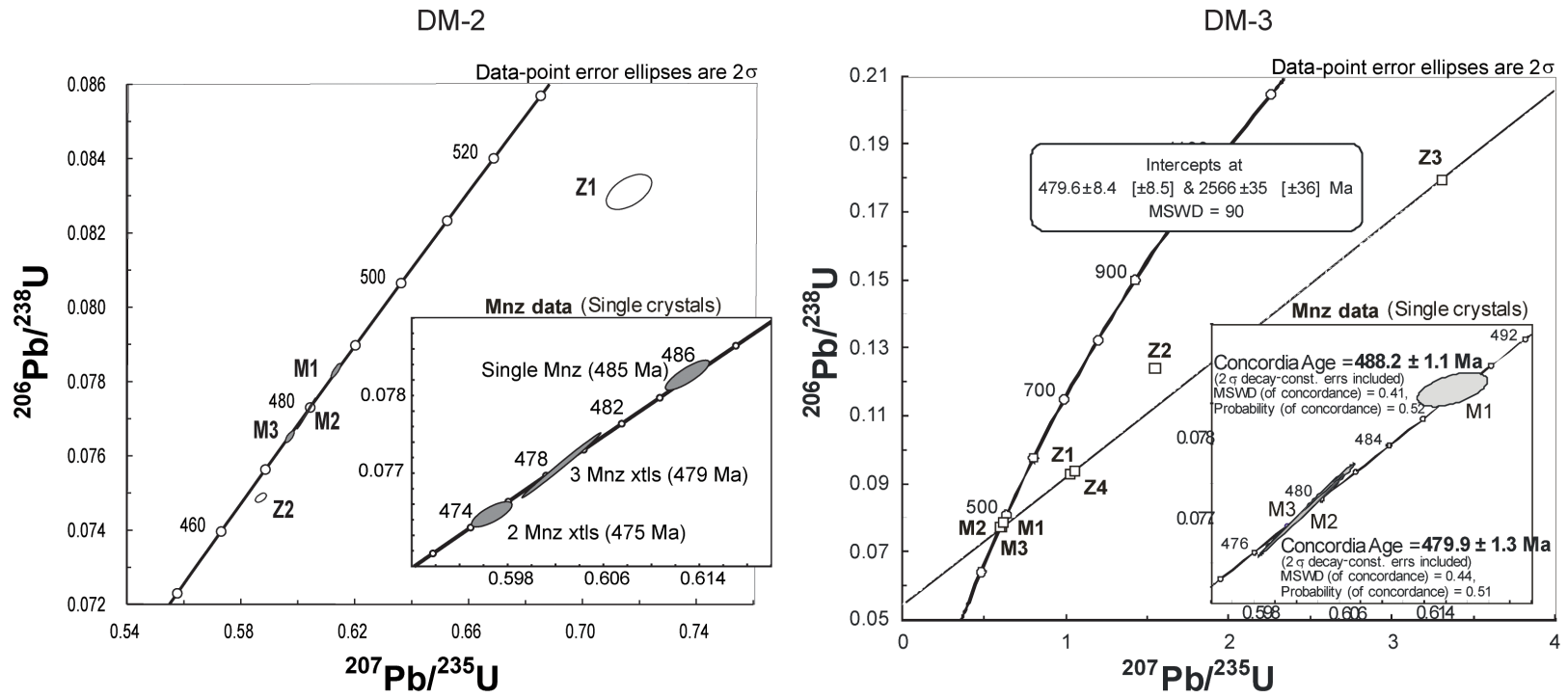

Figure 6. U-Pb CA-ID-TIMS data of the diorite dyke samples DM-2 and DM-3 (small white filled ellipses - zircon; grey ellipses - monazite). Locations are in Fig. 2a.

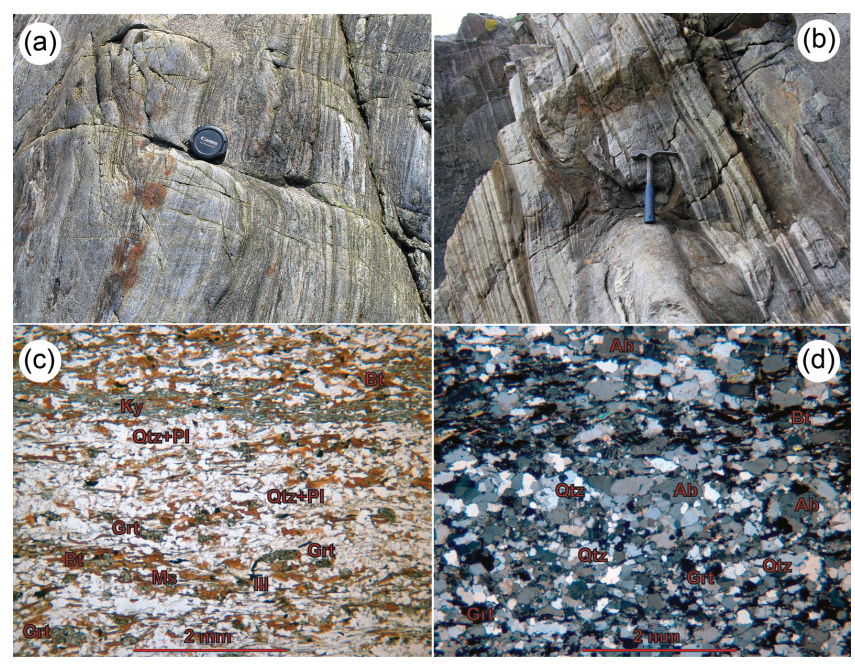

Figure 7. Metasedimentary qz-fsp gneisses and related rocks. (a) Leucosome veins (to right of the scale marker) parallel to the compositional banding. (b) Intrafolial folds related to the $S_{2}$ foliation superimposed on the compositional banding. (c) Microphotograph of a metapelite band (sample B1427). (d) Microphotograph of a metapsammite band (sample B22). Sample locations are in Fig. 2a.

and $\mathrm{Z} 3$ define a mixing line anchored at $480 \pm 8$ Ma by the concordant monazite and an upper intercept at $2.56 \mathrm{Ga}$, suggesting Proterozoic zircon inheritance. In this sample, monazite analyses were done using single crystals. Monazites M2 and M3 overlap each other and provide a concordant age of $480 \pm 1 \mathrm{Ma}$ (MSWD 0.44), while monazite M1 is concordant at $488 \mathrm{Ma}$, resembling the monazite from sample DM2. These data clearly demonstrate the presence of Cambro-
Ordovician (ca. 480-490 Ma) monazite in both dykes. A similar spread of early Ordovician monazite ages, such as those in sample DM-2, was reported by Fernández-Suárez et al. (2002) in the Cabo Ortegal nappe from leucosomes of the Chimparra gneiss, suggesting minor Devonian (ca. 386 Ma) overprint of Cambro-Ordovician monazite. The same authors also reported a zircon age of $487 \mathrm{Ma}$ from a leucosome in the mafic granulites. Therefore, we consider that the monazites provide the best estimate for the intrusion age of the felsic dykes DM-2 and DM-3, which would be bracketed by a minimum age of $480 \mathrm{Ma}$ (intercepts of the discordia lines) and a maximum age of 485-488 Ma (oldest concordant monazite fractions).

\subsection{Metasedimentary gneisses}

The upper unit of the tectonic imbricate in Masanteo peninsula is composed of high-pressure qz-fsp paragneisses with a paragenesis containing $\pm \mathrm{St} \pm \mathrm{Ky} \pm \mathrm{Rt} \pm$ Grt. These metasedimentary gneisses preserve a compositional layering formed by alternations of psammitic and pelitic layers and are also known as Cariño gneiss (Vogel, 1967). The paragneisses also show occasional leucosomes and have been strongly deformed during $D_{2}$ (Fig. 7a and b). The metapelitic layers are composed of $\mathrm{Ky}+\mathrm{Grt}+\mathrm{Bt}+$ $\mathrm{Ms} \pm \mathrm{St} \pm \mathrm{Hbl} \pm \mathrm{Czo} \pm \mathrm{Ilm} \pm \mathrm{Ttn}$, while the metapsammitic layers lack Ky and the other alumina-rich phases (Fig. 7c and d). Albert et al. (2015) reported a maximum depositional age of ca. $510 \mathrm{Ma}$ from this paragneiss, where the source for siliciclastic detritus was mostly continental. North of our area of study, the paragneisses are intruded by amphibolitized flaser gabbro (Fig. 2a), Fernández-Suárez et al. (2002) reported $400 \mathrm{Ma}(\mathrm{Ttn})$ and $386 \mathrm{Ma}(\mathrm{Mnz}) \mathrm{U}-\mathrm{Pb}$ ages from 


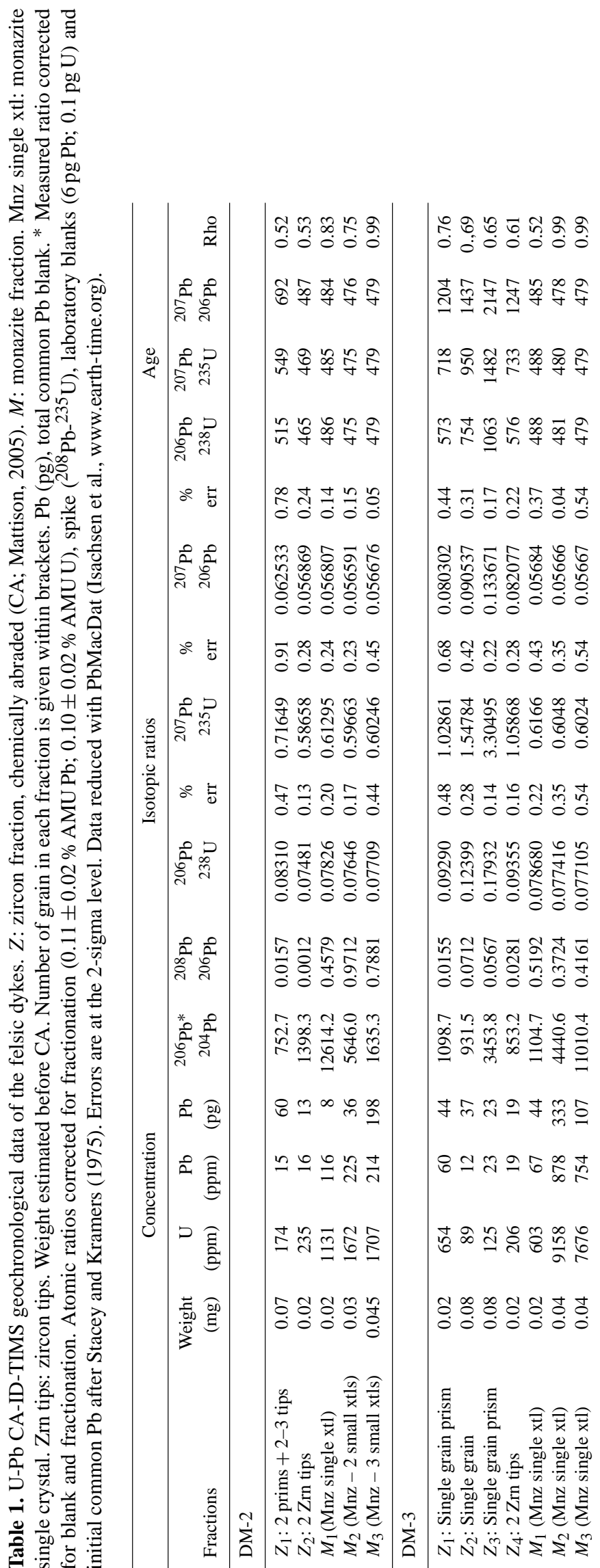

(a)

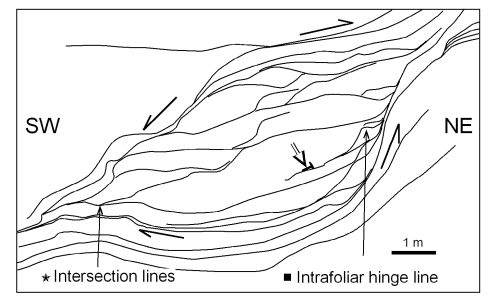

(b)

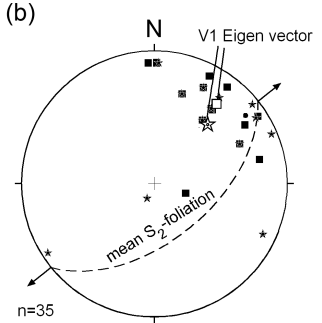

Figure 8. Relation of deformation structures inside and outside lozenge migmatitic bodies: (a) sketch showing the trace of the $S_{2}$ foliation in bounding shear zones and within the lozenge (location of observations in Fig. 4c); and (b) pole figure of main $S_{2}$ foliation, intersection lineation and intrafolial hinge lines within the lozenge in (a). Equal area projection, lower hemisphere projection also shows the V1 eigenvector and the mean $S_{2}$-foliation plane. The arrows indicate the orientation of the horizontal maximum extension inferred.

these gneisses. Peucat et al. (1990) provided a well-defined muscovite Ar-Ar plateau age of $376 \pm 2 \mathrm{Ma}$ from this gneiss in the Masanteo peninsula, marking the cooling of the whole nappe below $350{ }^{\circ} \mathrm{C}$ (muscovite blocking temperature; see discussion in Ordoñez-Casado et al., 2001).

Metamorphic peak conditions in metasedimentary gneisses in the Masanteo peninsula are $700^{\circ} \mathrm{C}$ and $1.2 \mathrm{GPa}$ (Fig. 5; Castiñeiras, 2005), consistent with the presence of St and the absence of eclogite or retroeclogite blocks in them. Peak $T$ conditions are comparable to those recorded in the underlying migmatitic qz-fsp gneisses, however there is a difference of $0.5 \mathrm{GPa}$ in peak pressure conditions. This difference in peak lithostatic pressure conditions represents a difference in depth of $\sim 13$ to $15 \mathrm{~km}$ between the migmatitic and the metasedimentary gneisses. Most outcrops examined show a gradual transition between migmatitic and metasedimentary gneisses, which is accommodated by the intense development of the blastomylonitic $S_{2}$ foliation. This contact is quite exposed in the Serrón beach (Figs. 2a and 12c), where a sub-horizontal shear zone deflects the $S_{2}$ foliation, indicating an extensional sense of shear relative to lithological layering.

\section{Structure}

\subsection{The main tectonic fabric}

Evidence of the structural evolution prior to eclogite facies deformation is rarely observed in Cabo Ortegal nappe rocks because the main tectonic fabric, $S_{2}$, (Figs. 3a, 4c, 7a), is so pervasive. The most common tectonites formed in relation to shear zones are planar ( $S$-tectonite) or plano-linear (LS-tectonite). $S_{2}$ foliation involved the formation of decompressive textures, such as the growth of large Phg bounded by Bt flakes that enclose small Grt (Fig. 4d and f), evidenc- 


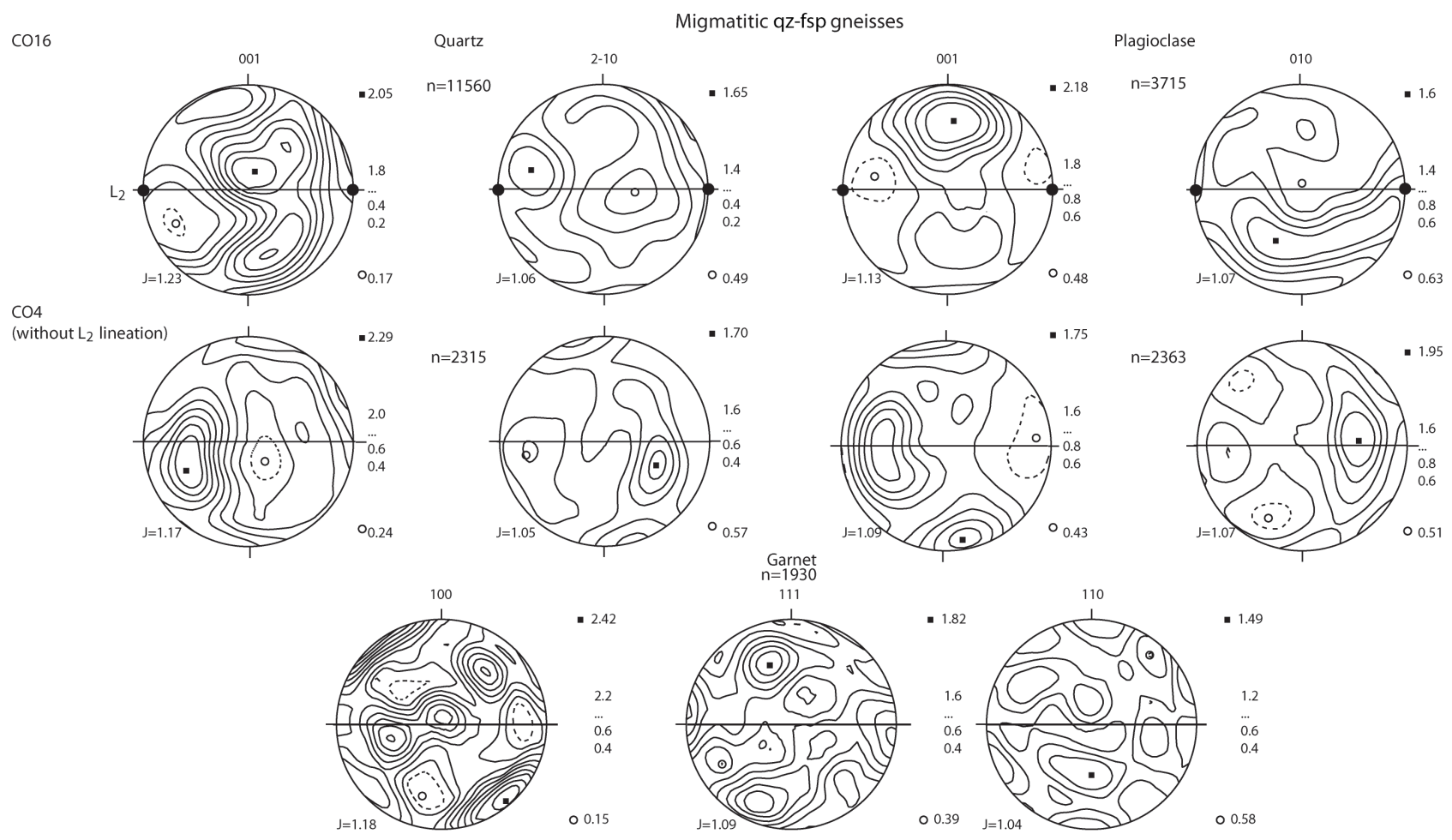

Metasedimentary qz-fsp gneisses
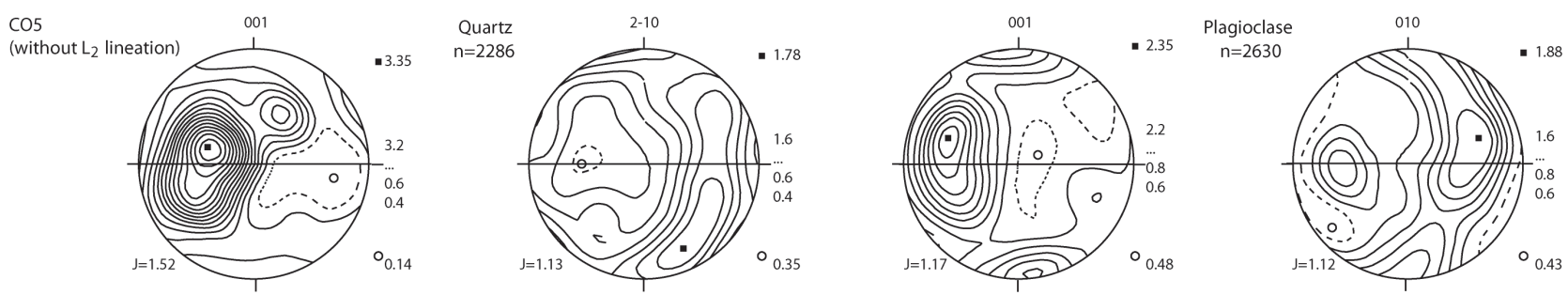

Figure 9. Crystallographic preferred orientation $(\mathrm{CPO})$ patterns in quartz and plagioclase, in relation to the main $S_{2}$ foliation in the qz-fsp gneisses. Sample locations are in Fig. 2. Contouring is in multiples of uniform distribution (Gaussian half width 15). Items indicated in the stereo plots are the following: bottom left, the $J$-index; right, the values of contours. Equal area projection, lower hemisphere. $S_{2}$ foliation is plotted E-W vertical and the $L_{2}$-lineation, if sufficiently developed, is plotted E-W horizontal. Crystallographic preferred orientation (CPO) pattern in garnet formed in the $S_{2}$-tectonic fabric in sample $\mathrm{CO}_{4}$ is also plotted.

ing a fast isothermal decompression during $D_{2}$-deformation (Fernández, 1997).

The lozenge-shaped bodies bounded by anastomosing shear zones, which preserve migmatitic layering within less deformed qz-fsp gneisses. The lozenges include rootless intrafolial fold hinges and an intersection lineation between the migmatitic layering and the lozenge shear walls. The orientation of the intersection lineation can be useful to infer kinematics during deformation. Eigenvector v1 orientation for the intersection and intrafolial hinge lines lie sub-parallel to N20E direction (Fig. 8), and the overall geometry is consistent with bulk strain controlled by flattening (Ponce et al., 2013).

Crystallographic preferred orientation (CPO) patterns of $\mathrm{Qz}, \mathrm{Pl}$, and Grt have low intensity during the development of
LS- and $S$-tectonites in $D_{2}$ and are comparable in metasedimentary and migmatitic gneisses (Fig. 9). The lack of a well-developed stretching lineation in samples $\mathrm{CO} 4$ and $\mathrm{CO} 5$ makes its kinematic interpretation difficult. The preferred orientation of $\mathrm{Qz} c$ axes is characterized by a single girdle of $c$ axes normal to the foliation plane in sample CO16; and by a single girdle in samples $\mathrm{CO} 4$ and $\mathrm{CO} 5$ dominated by a strong maximum within the girdle and parallel to the foliation. Such CPO patterns are usually found in fabrics formed at medium and high $T$, in relation to the dominant activity of the prism $<a>$ and rhomb $<a>$ slip systems (e.g. Law, 1990). 
(a)

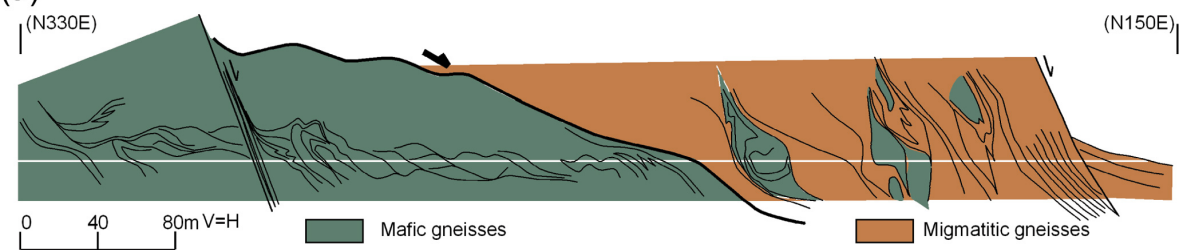

(b)
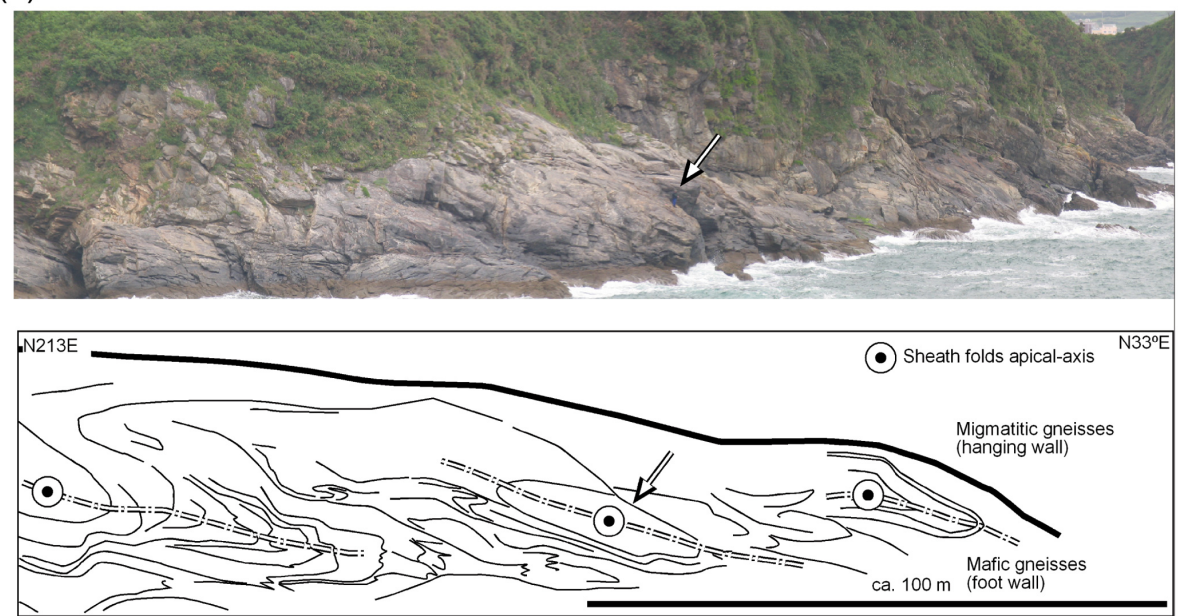

(c)
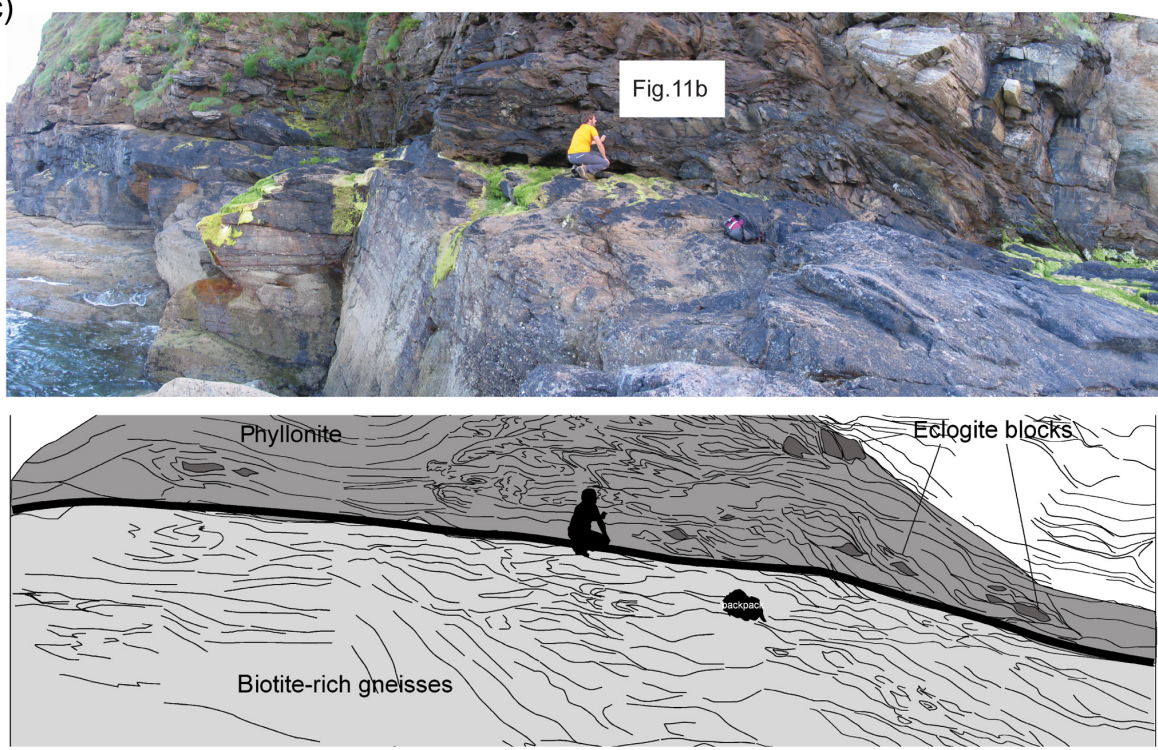

Figure 10. Coastal sections of the basal thrust (see Figs. 2a and 12a for locations). (a) Continuous section showing the contact between the mafic gneisses and the migmatitic gneisses. The white line represents the sea level. (b) Elliptical sections in sheath folds of decametric size in the lower domain of the basal thrust. The arrow points to an fisherman for scale, also used as reference in the sketch outlining the $S_{2}$ foliation underneath. (c) Phyllonitic domain in the basal thrust. Structures related to this domain are outlined in the sketch below the picture.

\subsection{The basal ductile thrust}

The normally pervasive blastomylonitic $S_{2}$ foliation is disrupted by a discrete high-strain shear zone. The layering and foliations intersect relative to the sense of shear indicate that is a basal ductile thrust, between the mafic gneisses and the migmatitic qz-fsp gneisses (Figs. 3 and 14a). The shear zone has a thickness $<100 \mathrm{~m}$. Three deformation domains can be differentiated. The associated structures decrease in size and the domains decrease in thickness towards the upper boundary of the ductile thrust, indicating the progressive localization of deformation. The lower domain affects the underlying mafic gneisses along a band ca. $50 \mathrm{~m}$ in thickness. It contains metric- and decametric-sized sheath folds. The orientation of 

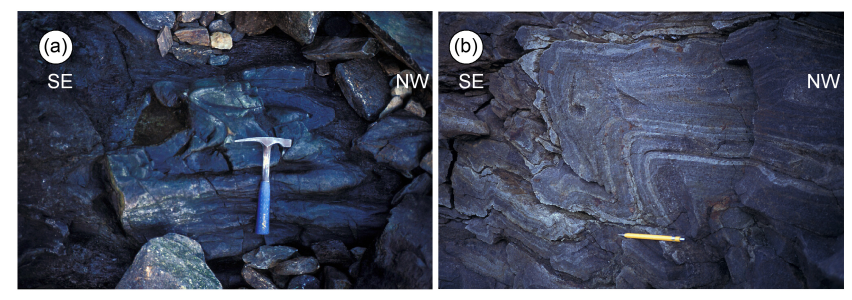

Figure 11. Non-cylindrical minor fold associated with the basal thrust: (a) sheath folds with apical axes perpendicular to the section view; and (b) type 3 fold interference pattern (after Ramsay, 1967) in the phyllonitic domain (see Fig. 10 for location).

angular spread of the fold hinges indicates NW-SE stretching (Fig. 10b).

The middle domain forms in biotite qz-fsp gneisses and includes eclogite blocks within the migmatites. Migmatitic leucosomic and restitic layers are interbedded and deformed ductilely. Metric asymmetrical folds develop vergence to the SE (Fig. 12a and c).

The upper domain contains $\sim 10 \mathrm{~m}$ thick phyllonites, frequently including mafic eclogite pods and boudins. The phyllonites are affected by shear bands, decimetric sheath folds, superposed folds and rotational complex structures (Figs. 10c and 11). Superposed shear folds show the type 3 (coaxial) interference pattern of folding (Ramsay, 1967) (Figs. 11 and 12). The apical axes of sheath folds point towards N20E, indicating maximum ductile extension along this direction.

\subsection{The internal structure of the migmatitic gneisses}

A group of decametric asymmetric folds, affecting the planar blastomylonitic $S_{2}$ foliation, dominates the internal structure. The folds are tight, overturned and vergent to the SE along the lower part of the migmatitic gneisses (Fig. 12a). They often have associated parasitic folds, and non-cylindrical horizontal hinges. Occasionally, minor folds relate to small thrust surfaces that imbricate eclogite pods parallel to the blastomylonitic $S_{2}$ foliation.

The shape of eclogite blocks and boudins was measured in exposed faces within the gneisses. The representation in a Flinn diagram using the shape of pods according to block sizes shows in Fig. 13 that most of the large eclogite blocks plot near to the plane strain field, while smaller eclogite bodies plot either in the constrictional or flattening fields. However, the results of this analysis are not a very strong argument because the eclogite bodies do not show a strongly dominant shape. The shapes were measured in 2-D sections, and the original shapes of these blocks is unknown. The long axis of eclogite bodies does not show a preferred orientation (to the right in Fig. 13).

The ca. $488 \mathrm{Ma}$ felsic dykes can be regarded as passive deformation markers during $\mathrm{D}_{2}$-deformation. A complex structure has been observed in the coastal section at the Serrón beach (Fig. 12b). In this section, the thickness of the migmatitic qz-fsp gneisses is less than $100 \mathrm{~m}$, and both bottom and top boundaries of this unit are quite exposed. Their thickness decreases progressively towards the SE. Migmatitic gneisses are affected by a shear zone in which the sense of the shear changes between the top and the bottom, producing rootless folds of opposite vergence in the felsic dioritic/granodioritic dykes and in the migmatitic banding. The larger structure reconstructed from both markers (the felsic dykes and the migmatitic banding) consists of an opposite vergence recumbent hinge defined by the competent dioritic dykes. The limbs are disrupted and boudinaged towards the horizontal high-strain zones located at the boundaries of the unit. This sandwiched structure indicates orthogonal stretching with the transport direction for the migmatitic gneisses towards the SE (Fig. 12b).

\subsection{The top detachment}

A horizontal discrete shear zone separating the metasedimentary and the migmatitic gneisses is exposed at the Serrón beach (Fig. 12b and c). A gradual transition between both types of gneisses is observed along the base of the cliffs. Deformation partitions into anastomosing $D_{2}$-shear bands preserving evidences of previous melting episodes (Figs. $4 \mathrm{e}$ and 7a).

The horizontal shear zone is $20 \mathrm{~m}$ in thickness and strongly deflects the migmatitic layering in extensional manner. Migmatitic layering and diorite dykes are disrupted and boudinaged progressively towards the upper high-strain surface (Fig. 12c). The deflection of the migmatitic layering, parasitic "drag" folds and the boudinage of the dioritic dykes indicate top to NW shear sense. Despite subsequent reequilibration under greenschist-facies conditions, evidencing a late reactivation, the mineral assemblages in the progressively less deformed bands within the detachment are basically the same as the high-grade qz-fsp gneisses described previously (Fig. 5).

\subsection{The upper $D_{3}$-recumbent fold}

The metasedimentary qz-fsp gneisses lie in the core of a $\mathrm{km}$-scale $D_{3}$-recumbent/overturned-synformal structure, outcropping towards the east side of the Masanteo peninsula (Fig. $1 \mathrm{~b}$ and $\mathrm{d}$ shows the location of the fold within the general cross-section of Cabo Ortegal nappe, after Marcos et al., 2002). This large-scale fold opens to the SE and has several parasitic cylindrical-folds and an associated crenulation cleavage. Intrafolial and sheath folds formed during the development of the $S_{2}$ foliation (Fig. 15c and d) are refolded by parasitic $D_{3}$-folds related to the recumbent fold (Fig. 14b). Detailed cross-sections of the recumbent structure have been constructed using the asymmetry of smallscale parasitic folds and the main $S_{2}$ foliation (Fig. 14). The fold axis plunges $5-30^{\circ}$ towards N20E. The fold attitude re- 


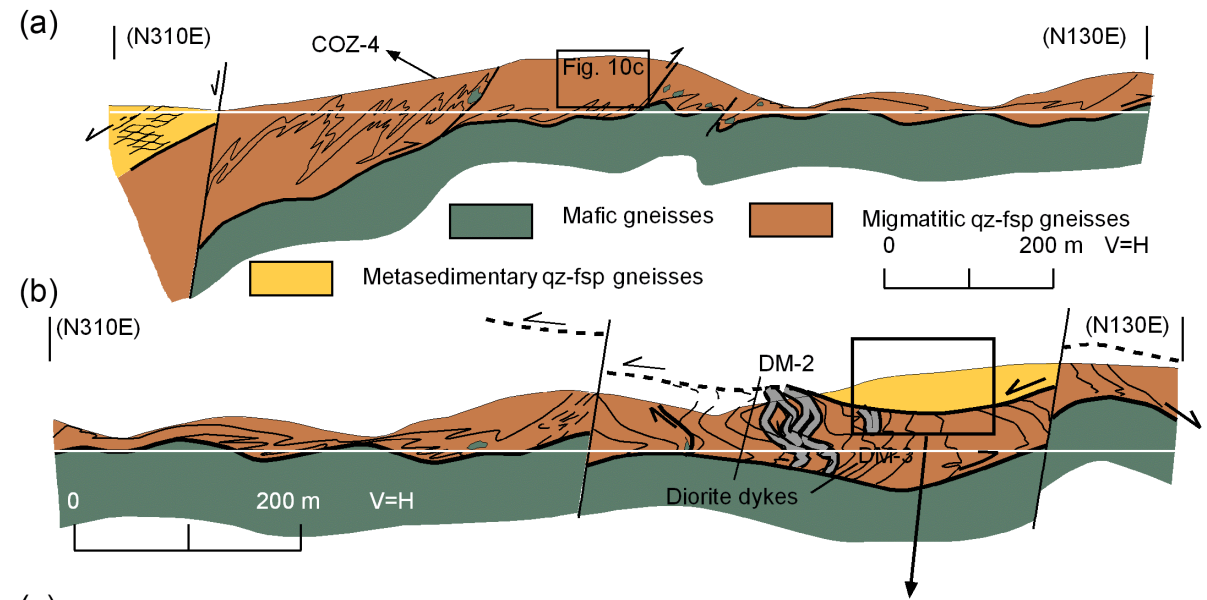

(c)

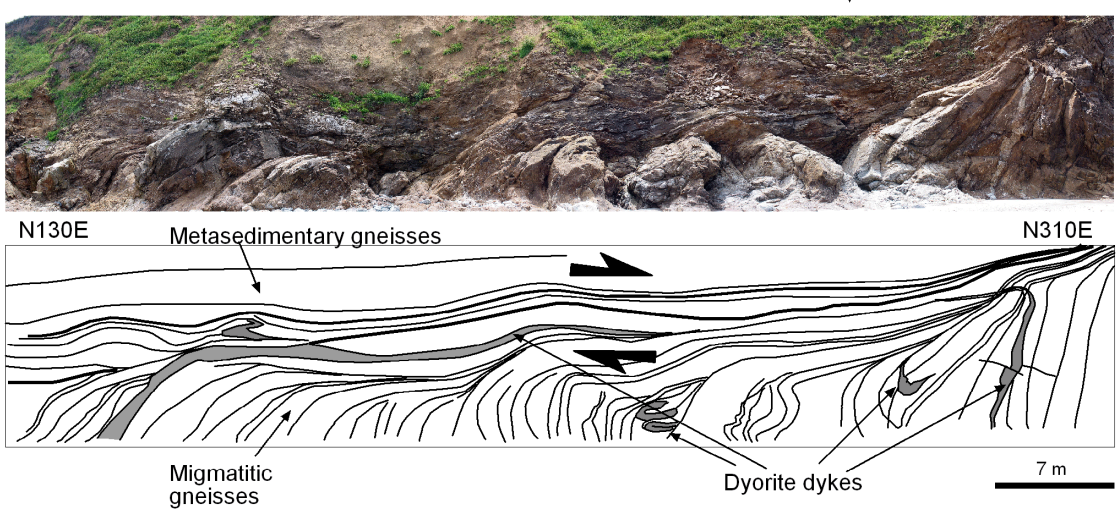

Figure 12. Geological sections showing the internal structure of the migmatitic qz-fsp gneisses and the locations of larger eclogite-blocks. Cross sections are located in Fig. 2a. The white lines represent the sea level. (a) In the northern section, the internal structure is characterized by asymmetrical folding and the presence of eclogite block-in-matrix close to the thrust. (b) The internal structure of the migmatitic qz-fsp gneisses is dominated by the presence of polyclinal folds bounded by the basal thrust and the upper normal detachment. (c) Photograph and sketch in the cliff of the Serrón beach showing an extensional detachment placing the metasedimentary gneisses on top of the migmatitic gneisses. Location of the sections is in Fig. 2a.
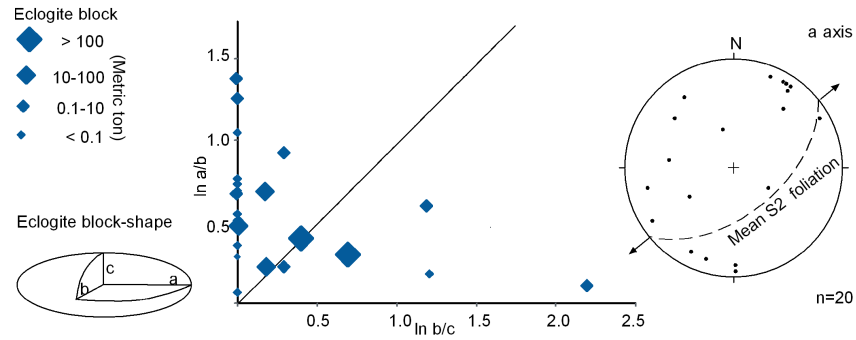

Figure 13. The shapes of the eclogite pods show a range of geometries in a Flinn diagram from prolate to oblate. The size of the symbols is proportional to size of the blocks.

quires that the reverse limb outcrops in the northeastern cliffs of Cabo Ortegal and only partially along the southeast shoreline. A late upright antiform refolds the recumbent synform (Fig. 15b and e). This late folding affects the crenulation cleavage (Fig. 14c), which equilibrated under greenschistfacies conditions.

\section{Metamorphic evolution in the gneisses}

The gneissic sequence in the Masanteo peninsula shows a complex tectonic record, including pre-Variscan and EoVariscan events. HP-HT metamorphism followed by rapid decompression leading to the formation of the $D_{2}$ tectonic fabric, based on the $M_{2}$ metamorphic assemblages defining the main foliation in the qz-fsp migmatites, eclogites and mafic granulites (Gil-Ibarguchi et al., 1990; Fernández, 1997; Galán and Marcos, 2000; Ábalos et al., 2003).

The Cambro-Ordovician intrusion of the felsic dykes at ca. $488 \mathrm{Ma}$ demonstrates a pre-Variscan tectonothermal event (Table 1; Fig. 6). The 488-486 Ma monazites from these discrete felsic dykes coincide in age with the monazite ages reported by Fernández-Suárez et al. (2002) also in migmatitic gneisses from other localities in the Cabo Ortegal nappe. 
(a)

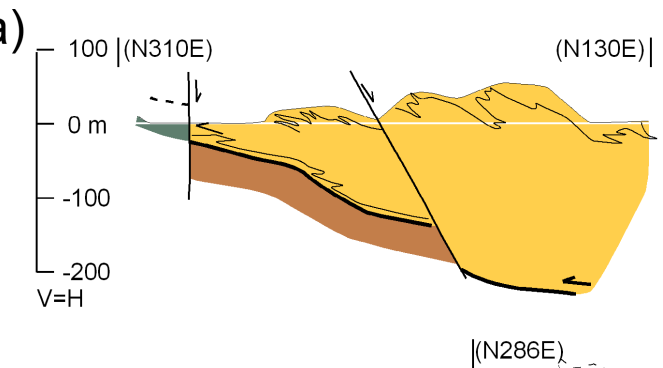

(b)

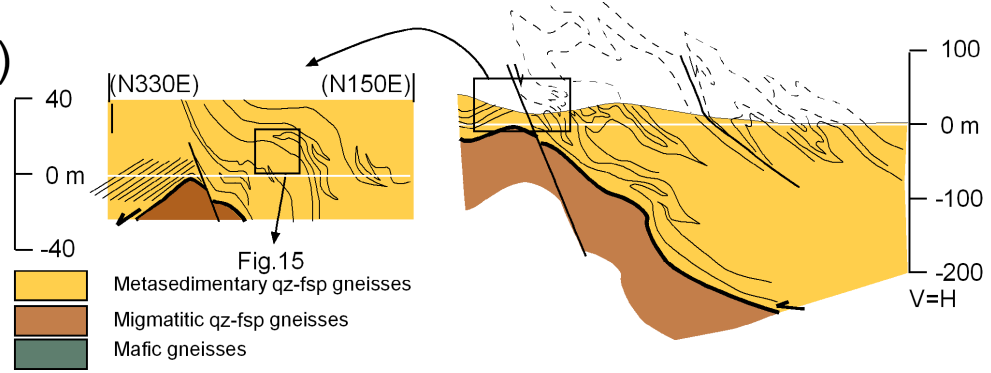

(c)

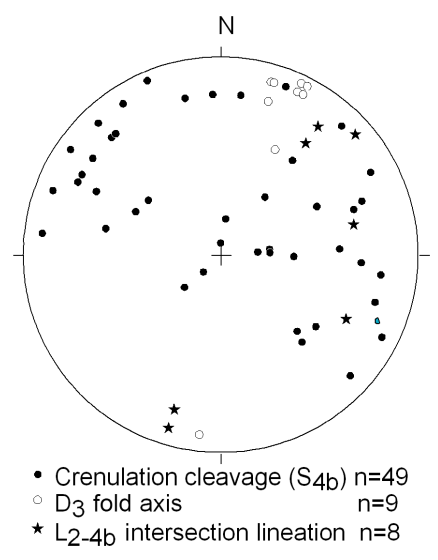

Figure 14. Geological sections of the $D_{3}$-recumbent syncline reconstructed from the small-scale parasitic folds that are folding the main $S_{2}$ foliation. Location of the sections is in Fig. 2a. White lines represent the sea level. (a) Northern outcrop section. (b) Southern outcrop section and the structural detail with location of Fig. 15. Note that the recumbent synform is affected by open-upright $D_{4 b}$-folds. (c) Crenulation cleavage $S_{4 b}, D_{3}$ fold axes and $\mathrm{L}_{2-4 b}$ intersection lineation is plotted in an equal area, lower hemisphere projection.

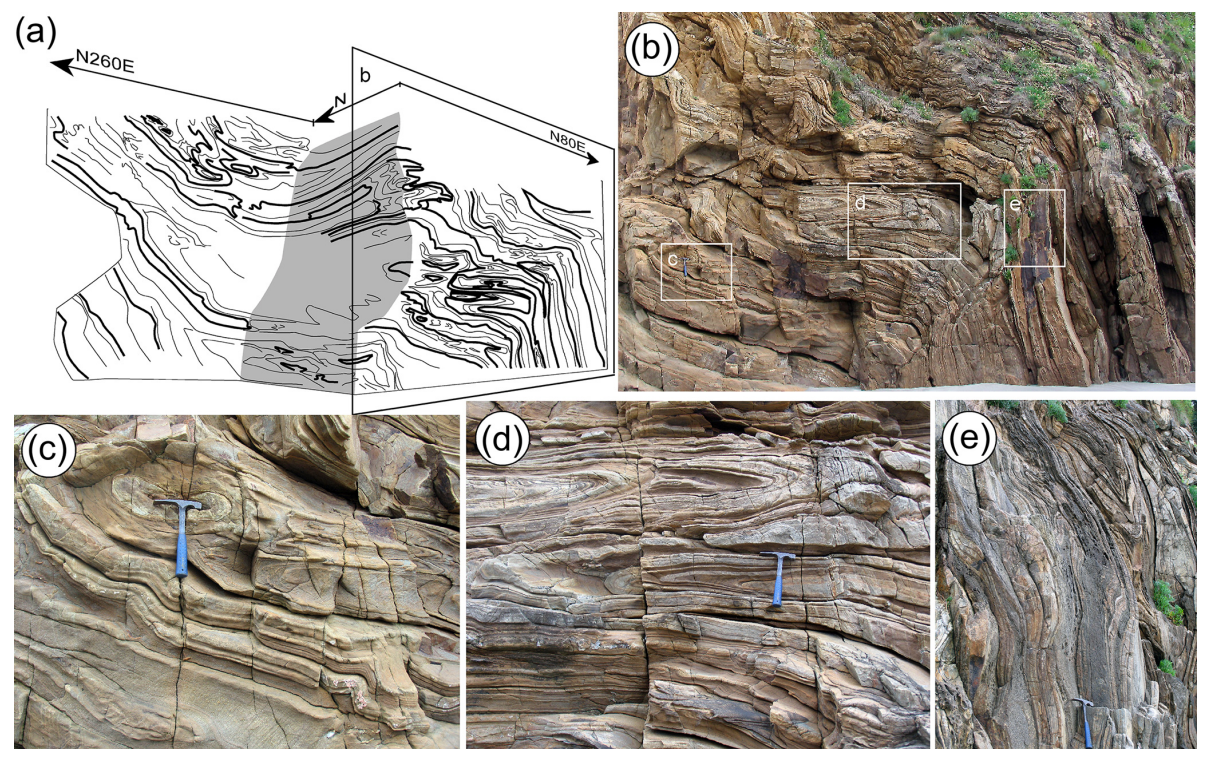

Figure 15. Small-scale parasitic folds related to the recumbent synform folding prior to $D_{2}$-isoclinal folds. Locations of outcrops are indicated in Figs. 3 and 14. (a) Sketch of the outcrop section. (b) W-E view of a monocline, with location of the photographs (c), (d), and (e). (c) The apical-section of a $D_{2}$-sheath-fold, behind the hammer, indicates a N-S stretching line. (d) $D_{2}$-intrafolial folds folded by a "Z" parasitic $D_{3}$-fold (reverse limb of the $D_{3}$-recumbent fold). (e) " $Z$ " parasitic $D_{3}$-fold rotated by the $D_{4 b}$-monocline.

These monazites have survived the high-pressure Devonian overprint. This could point to the presence of an early Ordovician metamorphic event similar to the one described by Abati et al. (1999) in equivalent units of the Órdenes complex. Such a pre-Variscan event would be consistent with the presence of coronitic textures in the Cabo Ortegal metagabbros (Galán and Marcos, 1997; Marcos et al., 2002). How- ever, to be able to tie these metastable early Ordovician monazites from Cabo Ortegal to a particular set of metamorphic conditions remains to be conclusively demonstrated. The high-grade eclogitic event is well-established by the ca. $390 \mathrm{Ma}$ U-Pb Zrn age from the eclogitic boudin in the migmatitic gneiss, (sample COZ4 located in Figs. 2a and 12a; Castiñeiras et al., 2010). In addition, the ca. $376 \mathrm{Ma}$ 
(a)

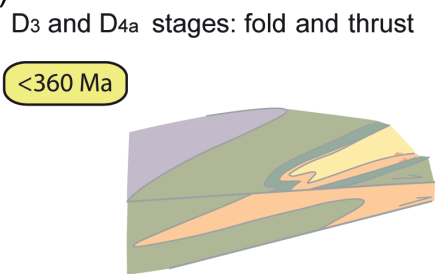

(b)

D2: Exhumation prior to Variscan collision

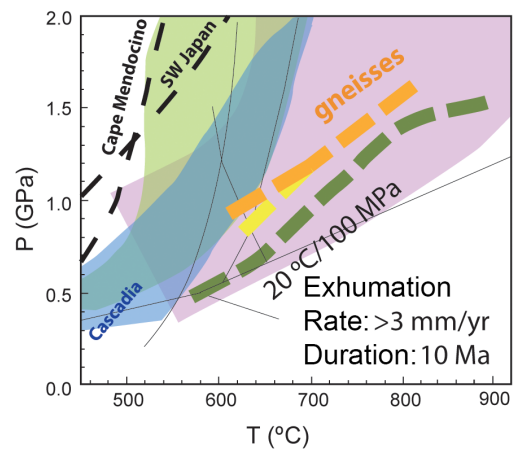

Cabo Ortegal nappe (D4b-stage) (after Marcos et al., 2002)

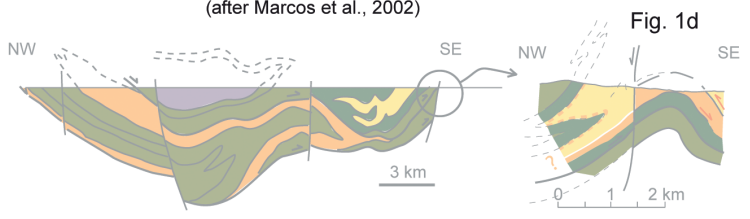

(c)

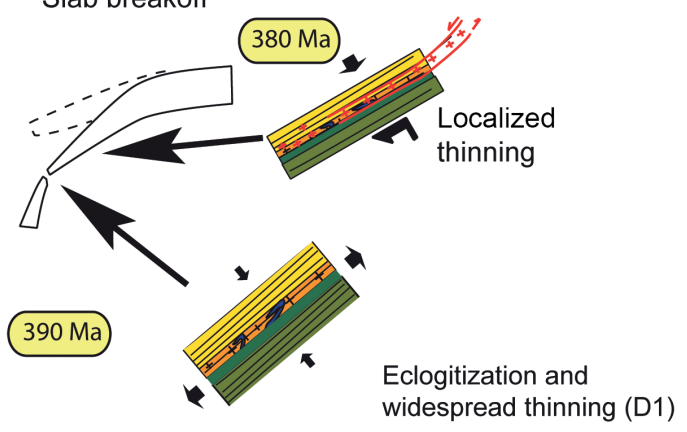

Eclogitization and
widespread thinning (D1)

Figure 16. Synthetic tectonic evolution of qz-fsp gneisses within the Cabo Ortegal nappe. (a) Simplified geological section of the Cabo Ortegal nappe at present, showing the detail of the structure in the Masanteo peninsula (cross section in Fig. 1d, modified from Marcos et al., 2002). Partially restored section to the left shows the relationships between $D_{3}$-recumbent folds and $D_{4 a}$-thrust. (b) $D_{2}$-stage (390-380 Ma) summarising the effect of progressive localization of deformation and thinning during exhumation. The P-T diagram (based on Fig. 5) is showing the retrograde P-T-t paths for migmatites, metasedimentary qz-fsp gneisses and mafic granulites compared to current subduction zones. (c) Slab breakoff could eclogitize the top of the mafic granulites during a widespread thinning of the tectonic sequence (Llana-Fúnez et al., 2004). (d) A Cambro-Ordovician melting event led to the injection of felsic dykes at the base of the qz-fsp gneisses coeval with leucosome in the mafic granulites (Fernandez-Suarez et al., 2002). Arrows indicate the inferred finite strain principal displacements.

muscovite Ar-Ar date from the paragneisses in the Masanteo peninsula provides a cooling age, which would be consistent with rapid cooling (ca. $90^{\circ} \mathrm{C} \mathrm{Ma}^{-1}$ ) and a relatively fast exhumation rate $\left(5.8 \mathrm{~mm} \mathrm{yr}^{-1}\right)$ associated with the $D_{2}$ deformation, following the eclogitic event (see discussion of U-Pb and Ar-Ar data in Ordoñez-Casado et al., 2001).

\section{Discussion}

\subsection{Tectonic evolution of gneisses at Masanteo}

The tectono-metamorphic and geochronological data reported in this paper based on the observations around the Masanteo peninsula are grouped into three stages (Fig. 16). The first stage is characterized by the assembly of a highgrade tectonic sequence composed of mafic granulites overlain by qz-fsp gneisses. The partial melting of the mafic granulites led to the injection of the felsic dykes into the base of the gneisses during the early Ordovician (ca. $490 \mathrm{Ma}$ ).

A Devonian subduction, producing the eclogite facies metamorphism dated at $390 \mathrm{Ma}$ (Peucat et al., 1990; SantosZalduegui et al., 1996; Ordóñez-Casado et al., 2001;
Fernández-Suárez et al., 2002, 2007; Castiñeiras et al., 2010), occurred $20 \mathrm{Ma}$ prior to the main Variscan subduction at ca. 370-360 Ma (i.e. Martínez-Catalán et al., 1997; Arenas et al., 2014; López-Carmona et al. 2014) and suggests the development of a complex collision during the assembly of Pangea.

The qz-fsp gneisses underwent an episode of partial melting after eclogitization (at ca. $390 \mathrm{Ma}$ ). Migmatitic qz-fsp layers are heterogeneously mylonitized along anastomosing shear bands that progressed to planar shear zones, incorporating eclogite blocks during $D_{2}$ (Figs. 3a and 10a). $D_{2-}$ tectonic fabrics have similar high temperature $\mathrm{CPO}$ patterns in migmatitic and metasedimentary qz-fsp gneisses consistent with flattening strain (Fig. 9). In addition, bulk flattening strain is also supported from the lozenged overall structure and the scattered orientation of the kinematic markers. Most of the tectonic pile thinning occurred during the development of the blastomylonitic $S_{2}$ foliation (i.e. Fernández, 1997; Llana-Fúnez et al., 2004) and before the progressive localization of strain. Lack of a persistent stretching lineation suggests non-plane strain, with orogeny parallel stretching accompanying shearing displacements. Additional thinning could have progressed through the reactivation of the NW- 
vergent top detachment (Fig. 12b and c). The common metamorphic and structural evolution for most of the rock units within the Cabo Ortegal nappe indicates a tectonic setting of coherent slab subduction in which extensive eclogitization and significant ductile thinning of the tectonic sequence are coeval. A scenario of downdip extension during ductile breakoff was suggested to produce observed structures and metamorphic imprint (Llana-Fúnez et al., 2004).

The tectono-metamorphic relationships of the basal ductile thrust and the normal detachment mapped in the Masanteo peninsula indicate that both discrete mechanical contacts were active before the development of the recumbent folding that affects the sequence of gneisses. These mechanical contacts upon their development became in fact the boundaries of the migmatitic qz-fsp gneisses (Figs. $1 \mathrm{~b}$ and 10c). The arrangement of the bounding shear zones defines an inclined E-dipping wedge with the migmatitic qz-fsp gneisses in the middle.

The internal structure of the migmatites consists of a rootless double recumbent hinge (Fig. 12). The metric sheath folds belonging to the mafic gneisses of the basal ductile thrust are consistent with an extension direction towards the SE (Fig. 10b). In addition, progressive localization of strain occurred during exhumation. Frequently, Phg phenoblasts are aligned parallel to the $S_{2}$ foliation of the migmatitic qzfsp gneisses, and are bounded by Bt flakes that enclose small prismatic shaped Grt (Fernández, 1997). These microstructures evidence the instability of Phg during decompression and indirectly point to exhumation at high rates. The starting point for the exhumation of the migmatitic qz-fsp gneisses and the metasedimentary qz-fsp gneisses differs by $0.5 \mathrm{GPa}$ (Fig. 5) and indicates that they have been initially juxtaposed by shearing displacements. The metamorphic pressure difference between both types of gneisses could be indicative that metasedimentary qz-fsp gneisses exhumed from maximum burial depths of $\sim 13$ to $15 \mathrm{~km}$ lower than the migmatitic qzfsp gneisses if we consider metamorphic pressure as lithostatic. However, in the context of subduction and exhumation of high-pressure rocks, the architecture of the qz-fsp migmatites, with a basal thrust and a top detachment, in addition to a tectonic regime dominated by flattening may suggest the development of a non-lithostatic pressure gradients leading to tectonic (vertical) extrusion. In this scenario, the reported difference in metamorphic pressure may contain a component of non-lithostatic stress (taking lithostatic stress as simply due to depth of burial), which will affect the conversion to depths. For instance, an overpressure (elevated mean stress) of 1.1 or 2 times the lithostatic pressure (e.g. Mancktelow, 1995, 2008; Moulas et al., 2013) would imply a difference in burial depths for the gneisses between 11 and $5.5 \mathrm{~km}$, respectively.

The migmatite wedge within the qz-fsp gneisses described here in the Cabo Ortegal nappe, is similar to the gneiss wedge reported within the high-pressure terranes of the Sambagawa HP rocks, sharing exhumation characteristics from lower to upper crustal levels (Osozawa and Wakabayashi, 2015). Another example comparable to what is reported here occurs in the exhumation of blueschist facies rocks of Leti Island in Indonesia (Kadarusman et al., 2010).

The final stage of large-scale structure development is dominated by the progressive deformation associated with the Variscan convergence, corresponding to the formation of kilometric-scale recumbent folds, thrusts and finally folding into upright or SE verging folds, described here for Cabo Ortegal rocks in the Masanteo peninsula as $D_{3}, D_{4 \mathrm{a}}$, and $D_{4 \mathrm{~b}}$, respectively (Fig. 16a). The late evolution of the Cabo Ortegal nappe and its kinematics (Marcos et al., 2002) is consistent and coeval with the deformation recorded in the underlying autochthonous rock sequence in relation to the Variscan belt (Matte, 1968; Pérez-Estaún et al., 1991), and led to the crustal thickening necessary to drive the deformation and metamorphism of the autochthon beneath.

\subsection{Characteristics of the exhumation of Cabo Ortegal nappe rocks}

The development of the main tectonic foliation in Cabo Ortegal nappe rocks, defined by mineral assemblages from eclogite facies to greenschist facies, indicates that the structure formed during the progressive exhumation from highpressure conditions to mid-crustal depths (Galán and Marcos, 2000; Marcos et al., 2002) (Fig. 5). In this contribution, we would like to highlight that the metamorphic evolution of two major rock units in the Cabo Ortegal nappe, the mafic granulites and the qz-fsp gneisses, have parallel P-T trajectories during their tectonic exhumation from eclogite to greenschist facies conditions (Fig. 16b). In the first instance, this suggests a common process and scenario for the exhumation of high-pressure rocks to mid-crustal depths prior to their final emplacement. In fact, it is possible to characterize the exhumation path in terms of cooling during decompression (the common slope of P-T paths in Fig. 16b), which may be regarded as indicative of this particular tectonic setting. Given that ages are available at peak pressure conditions and at midcrustal depths, exhumation rates can also be calculated from the data summarized before.

The exhumation of either the mafic granulites or the gneisses in Fig. 16b involves a cooling of $>200^{\circ} \mathrm{C}$ for a decompression of $1 \mathrm{GPa}$, most of it associated with the vertical component of movement in the crust. For a similar depth range, the amount of cooling during decompression is comparable to present-day subduction zones, in particular to the trajectory in the south-west Japan subduction zone (trajectory SWJ from Fig. 4 in Yamasaki and Seno, 2003 in included in Fig. 16b). The positive P-T slopes are characteristic of subducting slabs in active subduction zones (e.g. Hacker et al., 2003; Yamasaki and Seno, 2003). Therefore, based on this observation, we infer that the exhumation of Cabo Ortegal nappe rocks began while the subduction zone was still during the initial stage of exhumation. This is in 
contrast to P-T paths from equivalent high-pressure rocks in the Órdenes Complex, where adiabatic decompressive paths were inferred during exhumation from eclogite facies conditions (Arenas et al., 1995; Martínez-Catalán et al., 1997). Adiabatic decompressive paths are related to the very rapid exhumation of small fragments, not allowing cooling during ascent, however this is unlikely in the case of coherent slabs (Kylander-Clark et al., 2012).

The available ages at peak metamorphic conditions and at mid-crustal depths provide time constraints for the exhumation process, which might involve at least $140 \mathrm{~km}$ of horizontal displacement onto the continental margin. A rate of $>3 \mathrm{~mm} \mathrm{yr}^{-1}$ vertical component for migmatitic gneisses can be estimated, if all metamorphic pressure is regarded as corresponding to lithostatic pressure. These rates are half of those previously reported (Ordóñez-Casado et al., 2001), and are comparable to those reported in other parts of the Variscan orogeny, the Alps or the Himalayas. When compared with present-day subduction zones and numerical models the exhumation rates fall at the slow end member of scenarios (Gerya et al., 2002; Kylander-Clark et al., 2012; Burov et al., 2014). If the dislocation creep deformation mechanism observed (from tectonic fabrics and microstructures) to control internal deformation in part of the gneissic units (Fig. 9) were to be dominant across all of the Cabo Ortegal nappe it would imply, according to numerical models by Gerya and Stöckhert (2002), subduction rates 6 times higher than exhumation rate, still at the slower end for other subduction zones. The metamorphic evolution during the exhumation of Cabo Ortegal nappe rocks shows a significant difference with the inferred P-T path in other ancient and current subduction zones compiled by KylanderClark et al. (2012): the exhumation path is overall 100$200^{\circ} \mathrm{C}$ hotter than the warmest currently active (e.g. SW Japan or the Pacific Northwest), and most of the exhumation took place under conditions of slab melting. Melting occurring during a pervasive deformation episode will impart extreme weakening and ductile behaviour to rocks (e.g. Rosenberg and Handy 2005; Rutter et al., 2006), ultimately to the whole crustal section. This environment should promote widespread thinning in the subducting slab in which the Cabo Ortegal nappe was involved during plate convergence prior to the Variscan collision.

\section{Conclusions}

The structural relationships of the high-grade mafic and qzfsp gneissic bodies along the Masanteo peninsula provide valuable insights to understand the polyorogenic origin of the HP-HT Cabo Ortegal nappe. The Cambro-Ordovician (ca. 480-490 Ma) intrusion of felsic dykes within the migmatitic qz-fsp gneisses was coeval with the formation of leucosome in the underlying mafic granulites. A second melting event partially affected the qz-fsp gneisses coevally with the eclogitization of the whole lower crustal section during an early Variscan high-pressure episode (ca. 400-390 Ma). During the subsequent fast exhumation (ca. $380 \mathrm{Ma}$ ) the original rock sequence was largely thinned by dominant bulk flattening associated to the development of a main blastomylonitic foliation. Immediately after, at ca. $360 \mathrm{Ma}$, Cabo Ortegal nappe rocks, already at mid-crustal depths, were involved in the final Variscan collision that emplaced the ensemble of allochthonous complexes over the Iberian microplate, at the edge of Gondwana.

Progressive strain localization during exhumation triggered the development of anastomosing shear bands, enclosing lenticular or lozenge-shaped bodies. Strain weakening associated with hydration and retrogression during deformation in bounding shear zones prevented further pervasive deformation and retrogression into the lozenges. The geometric arrangement of ductile shear zones bounding the gneisses at separate tectonic stages during the exhumation, forming a basal ductile thrust and a top detachment, gave way to the development of an internal migmatite wedge within the qzfsp gneisses, consequence of the localization of strain during bulk thinning.

The exhumation path from eclogite facies conditions to mid-crustal depths in qz-fsp gneisses, estimated in this contribution around $2{ }^{\circ} \mathrm{C} / 100 \mathrm{MPa}$, is parallel to the trajectory in adjacent mafic high-pressure granulites and to the calculated distribution of temperature with depth in currently active subduction zones. This suggests that the metamorphic and also the structural record associated with the process of exhumation is comparable to present-day tectonic scenarios. It must be highlighted that the absolute temperatures for the exhumation path are substantially higher with respect to current settings, by approximately $100-200^{\circ} \mathrm{C}$. Such high temperatures can put the exhumation path into slab melting conditions, which ultimately would favour an extreme ductile behaviour of the whole rock sequence during deformation. This may have been the case during the stretching of the lower crustal rock sequence now preserved in the upper unit of the Cabo Ortegal nappe.

Author contributions. Francisco José Fernández and Alberto Marcos carried out the fieldwork and mapping. Sergio Llana-Fúnez measured and plotted the crystallographic preferred orientation of qz-fsp gneisses. Pablo Valverde-Vaquero and Pedro Castiñeiras determined the ages of the diorite dykes and the eclogite sample, respectively. Francisco José Fernández prepared the manuscript with contributions from all co-authors.

Acknowledgements. In 1988, Francisco José Fernández initiated his research career in the Masanteo peninsula under the supervision of Professor Alberto Marcos and aimed by Andrés Pérez-Estaún. Revisiting the area 25 years later brings new light and some understanding to Cabo Ortegal geology. Authors thank their colleagues for continuing discussion about the tectonic evolution 
of Cabo Ortegal. Research funds from grants CGL2011-22728, CGL2011-23628/BTE, CGL2012-38786 and CGL2014-53388-P by the Spanish government are acknowledged. Pedro Castiñeiras stay at Stanford University was funded by CSIC grant PA1002435. This paper benefitted from the general and specific comments of the reviewers Neil S. Mancktelow and Thomas Blenkinsop. We thank the editor Ernie Rutter for extensive feedback and criticism on the earlier versions of the manuscript.

Edited by: E. H. Rutter

\section{References}

Ábalos, B., Puelles, P., and Gil Ibarguchi, J. I.: Structural assemblage of high-pressure mantle and crustal rocks in a subduction channel (Cabo Ortegal, NW Spain), Tectonics, 22, 1006, doi:10.1029/2002TC001405, 2003.

Abati, J., Dunning, G. R., Arenas, R., Diaz García, F., Gonzalez Cuadra, P., Martinez Catalán, J. R., and Andonaegui, P.: Early Ordovician orogenic event in Galicia (NW Spain): evidence from $\mathrm{U}-\mathrm{Pb}$ ages in the uppermost unit of the Ordenes Complex, Earth Planet. Sci. Lett., 165, 213-228, 1999.

Albert, R., Arenas, R., Sánchez-Martínez, S., and Gerdes, A.: The eclogite facies gneises of the Cabo Ortegal Complex (NW Iberian Massif): Tectonothermal evolution and exhumation model, J. Iber. Geol., 38, 389-406, 2012.

Albert, R., Arenas, R., Gerdes, A., Sánchez-Martínez, S., Fernández-Suárez, J., and Fuenlabrada, J. M.: Provenance of the Variscan Upper Allochthon (Cabo Ortegal Complex, NW Iberian Massif), Gondwana Res., 28, 1434-1448, 2015.

Arenas, R., Gil Ibarguchi, J. I., González-Lodeiro, F., Klein, E., Martínez Catalán, J. R., Ortega Gironés, E., de Pablo-Maciá, J. G., and Peinado, M.: Tectonostratigraphic units in the complexes with mafic and related rocks of the NW of the Iberian Massif, Hercynica, 2, 87-110, 1986.

Arenas, R., Rubio-Pascual, F. J., Díaz-García, F., and Martínez Catalán, J. R.: High-pressure micro-inclusions and development of an inverted metamorphic gradient in the Santiago-schists (Órdenes-Complex, NW Iberian Massif, Spain) - evidence of subduction and syncollisional decompression, J. Metamorph. Geol., 13, 141-164, 1995.

Arenas, R., Martínez Catalán, J. R., Sánchez-Martínez, S., DíazGarcía, F., Abati, J., Fernández-Suárez, J., Andonaegui, P., and Gómez-Barreiro, J.: Paleozoic ophiolites in the Variscan suture of Galicia (northwest Spain): Distribution, characteristics and meaning, in: 4-D Framework of Continental Crust, edited by: Hatcher, R. D., Carlson, M. P., McBride, J. H., and Martínez Catalán, J. R., Geological Society of America Memoir, Boulder, Colorado, 200, 425-444, 2007.

Arenas, R., Fernández Díez, R., Sánchez Martínez, S., Gerdez, A., Fernández-Suárez, J., and Albert, R.: Two-stage collision: exploring the birth of Pangea in the Variscan terranes, Gondwana Res., 25, 756-763, 2014.

Bayer, R. and Matte, P.: Is the mafic/ultramafic massif of Cabo Ortegal a nappe emplaced during a Variscan obduction? - A new gravity interpretation, Tectonophysics 57, 9-18, 1979.

Beaumont, C., Jamieson, R. A., Nguyen, M. H., and Medvedev, S.: Crustal channel flows: 1 . Numerical models with applications to the tectonics of the Himalayan-Tibet orogeny, J. Geophys. Res., 109, B06406, doi:10.1029/2003JB002809, 2004.

Bird, P.: Initiation of intracontinental subduction in the Himalaya, J. Geophys. Res., 83, 4975-4987, 1978.

Burov, E., Francois, T., Agard, P., Le Pourhiet, L., Meyer, B., Tirel, C., Lebedev, S., Yamato, P., and Brun, J.-P.: Rheological and Geodynamic Controls on the Mechanisms of Subduction and HP/UHP Exhumation of Crustal Rocks during Continental Collision: Insights from Numerical Models, Tectonophysics, 631, 212-250, 2014a.

Burov, E., Francois, T., Yamato, P., and Wolf, S.: Mechanisms of continental subduction and exhumation of HP and UHP rocks, Gondwana Res., 25, 464-493, 2014b.

Brown, D., Llana-Fúnez, S., Carbonell, R., Alvarez-Marron, J., Marti, D., and Salisbury, M. H.: Laboratory measurements of Pwave and S-wave velocities across a surface analog of the continental crust-mantle boundary: Cabo Ortegal, Spain, Earth Planet. Sc. Lett., 285, 27-38, 2009.

Castiñeiras, P.: Origen y evolución tectonotermal de las unidades de O Pino y Cariño (Complejos Alóctonos de Galicia), Lab. Xeol. Laxe, Serie Nova Terra, 28, A Coruña, Spain, p. 279, 2005.

Castiñeiras, P., Gómez-Barreiro, J., Fernández, F. J., and Aguilar, C.: Power and pitfalls of trace element geochemistry in zircon from high-temperature-high-pressure rocks: Some examples from NW Spain, Goldschmidt Conference Abstracts, Goldschmidt Conference, Knoxville, 30 Tennessee, USA, 13-18 June 2010, 2010.

Chemenda, A. I., Mattauer, M., Malavieille, J., and Bokun, A. N.: A mechanism for syncollisional rock exhumation and associated normal faulting: results from physical modelling, Earth Planet. Sc. Lett., 132, 225-232, 1995.

Davis, D. M., Suppe, J., and Dahlen, F. A.: Mechanics of fold-andthrust belts and accretionary wedges, J. Geophys. Res., 88, 1153$1172,1983$.

England, P. C. and Holland, T. J. B.: Archimedes and the Tauern eclogites: the role of buoyancy in the preservation of exotic eclogite blocks, Earth Planet. Sc. Lett., 44, 287-294, 1979.

Escher, A. and Beaumont, C.: Formation, burial and exhumation of basement nappes at crustal scale: a geometric model based on the Western Swiss-Italian Alps, J. Struct. Geol., 19, 955-974, 1997.

Díaz-García, F., Arenas, R., Martínez-Catalán, J. R., del Tanago, J. G., and Dunning, G. R.: Tectonic evolution of the Careon ophiolite (northwest Spain): A remnant of oceanic lithosphere in the Variscan belt, J. Geol., 107, 587-605, 1999.

Fernández, F. J.: Estructuras desarrolladas en gneisses bajo condiciones de alta P y T (Gneisses de Chímparra, Cabo Ortegal, A Coruña, Galicia, España), Serie Nova Terra Laboratorio Xeológico de Laxe, 13, Edicios do Castro, Sada (Spain), 249 pp., 1997.

Fernández, F. J. and Marcos, A.: Mylonitic foliation development by heterogeneous pure shear under high-grade conditions in quartzofeldspathic rocks (Chimparra Gneiss Formation, Cabo Ortegal Complex, NW Spain), in: Basement Tectonics, Europe and other Regions, edited by: Oncken, O. and Janssen, C., 11, 17-34, 1996.

Fernández-Suárez, J., Corfu, F., Arenas, R., Marcos, A., MartínezCatalán, J. R., Díaz García, F., Abati, J., and Fernández, F. J.: $\mathrm{U}-\mathrm{Pb}$ evidence for a polyorogenic evolution of the HP-HT units 
of the NW Iberian Massif, Contrib. Mineral. Petr., 143, 236-253, 2002.

Fernández-Suárez, J., Arenas, R., Abati, J., Martínez Catalán, J. R., Whitehouse, M. J., and Jeffries, T. E.: U-Pb chronometry of polymetamorphic high-pressure granulites: an example from the allochthonous terranes of the NW Iberian Variscan belt, in: 4-D Framework of Continental Crust, edited by: Hatcher Jr., R. D., Carlson, M. P., McBride, J. H., and Martínez Catalán, J. R., Geological Society of America, Memoir, Boulder, Colo. Geological Society of America, 200, 469-488, 2007.

Galán, G. and Marcos, A.: Geochemical evolution of high-pressure mafic granulites from the Bacariza formation (Cabo Ortegal Complex, NW Spain): an example of a heterogeneous lower crust, Geol. Rundsch., 86, 539-555, 1997.

Galán, G. and Marcos, A.: The metamorphic evolution of the highpressure mafic granulites of the Bacariza Formation (Cabo Ortegal Complex, hercynian belt, northwest Spain), Lithos, 54, 139$171,2000$.

Gerya, T. V. and Stöckhert, B.: Exhumation rates of high pressure metamorphic rocks in subduction channels: The effect of Rheology: Geophys. Res. Lett., 29, 1-4, 2002.

Gerya, T. V., Stöckhert, B., and Perchuk, A. L.: Exhumation of highpressure metamorphic rocks in a subduction channel: A numerical simulation, Tectonics, 21, 1-15, 2002.

Gerya, T. V., Perchuk, L. L., and Burg, J. P.: Transient hot channels: Perpetrating and regusgitating ultrahigh-pressure, hightemperature crust-mantle associations in collision belts, Lithos, 103, 236-256, 2008.

Gibbons, W. and Moreno, T. (Eds): The Geology of Spain, The Geological Society, London, 2002.

Gil Ibarguchi, J. I. and Ortega Gironés, E.: Petrology, structure and geotectonic implications of glaucophane-bearing eclogites and related rocks from the Malpica-Tuy (MT) unit, Galicia, northwest Spain, Chem. Geol., 50, 145-162, 1985.

Gil Ibarguchi, J. I., Mendia, M. S., Girardeau, J., and Peucat, J. J.: Petrology of eclogites and clinopyroxene-garnet metabasites from the Cabo Ortegal Complex (northwestern Spain), Lithos, 25, 133-162, 1990.

Girardeau, J., Gil Ibarguchi, J. I., and Ben Jamaa, N.: Evidence for a heterogeneous Upper Mantle in the Cabo Ortegal Complex, Spain, Science, 245, 1231-1233, 1989.

Holdaway, M. J.: Stability of andalusite and the aluminum silicate phase diagram, Am. J. Sci., 271, 97-131, 1971.

Isachsen, C. E., Coleman, D. S., and Schmitz, M.: PbMacDat program, available at: http://www.earthtime.org (last access: 2015), 2007.

Kadarusman, A., Maruyama, S., Kaneko, Y., Ota, T., Ishikawa, A., Sopaheluwakan, J., and Omori, S.: World's youngest blueschist belt from Leti Island in the non-volcanic Banda outer arc of eastern Indonesia, Gondwana Res., 18, 189-204, 2010.

Kylander-Clark, A. R. C., Hacker, B. R., and Mattinson, C. G.: Size and exhumation rate of ultrahigh-pressure terranes linked to orogenic stage, Earth Planet. Sc. Lett., 321/322, 115-120, 2012.

Law, R. D.: Crystallographic fabrics: a selective review of their applications to research in structural geology, in: Deformation Mechanisms, Rheology and Tectonics, edited by: Knipe, R. J. and Rutter, E. H., Geological Society of London Special Publications, London, 54, 335-352, 1990.
Llana-Fúnez, S. and Marcos, A.: Convergence in a thermally softened thick crust: Variscan intracontinental tectonics in Iberian plate rocks, Terra Nova, 19, 393-400, 2007.

Llana-Fúnez, S., Marcos, A., Galán, G., and Fernández, F. J.: Tectonic thinning of a crust slice at high pressure and high temperature by ductile-slab breakoff (Cabo Ortegal Complex, northwest Spain), Geology, 32, 453-456, 2004.

Llana-Fúnez, S., Marcos, A., and Kunze, K.: Strain geometry in Concepenido eclogites during widespread HP deformation (Cabo Ortegal complex, NW Spain), Tectonophysics, 401, 198-216, 2005.

López-Carmona, A., Abati, J., Pitra, P., and Lee, J. K. W. Retrogressed lawsonite blueschists from the NW Iberian Massif: $P$ $T$ - $t$ constraints from thermodynamic modelling and ${ }^{40} \mathrm{Ar} /{ }^{39} \mathrm{Ar}$ geochronology, Contrib. Mineral. Petrol., 167, 987-1007, 2014.

Mancktelow, N. S.: Nonlithostatic pressure during sediment subduction and the development and exhumation of high pressure metamorphic rocks, J. Geophys. Res., 100, 571-583, 1995.

Mancktelow, N. S.: Tectonic pressure: theoretical concepts and modelled examples, Lithos, 103, 149-177, 2008.

Marcos, A.: Cabalgamientos y estructuras menores asociadas originados en el transcurso de una nueva fase herciniana de deformación en el occidente de Asturias (NW de España) (NW de España). Breviora Geológica Astúrica, 15, 59-64, 1971.

Marcos, A. and Farias, P.: La estructura de las láminas inferiores del Complejo de Cabo Ortegal y su autóctono relativo (Galicia, NW España), Trabajos de Geología, Universidad de Oviedo, 21, 201-220, 1999.

Marcos, A., Marquínez, J., Pérez-Estaún, A., Pulgar, J. A., and Bastida, F.: Nuevas aportaciones al conocimiento de la evolución tectonometamórfica del Complejo de Cabo Ortegal (NW de España), Cuad. Lab. Xeol. Laxe, 7, 125-137, 1984.

Marcos, A., Farias, P., Galán, G., Fernández, F. J., and Llana-Fúnez, S.: Tectonic framework of the Cabo Ortegal Complex: a slab of lower crust exhumed in the Variscan orogen (northwestern Iberian Peninsula), edited by: Martínez-Catalán, J. R., Hatcher, R. D. J., Arenas, R., and Díaz García, F., Boulder, Colorado, Geol. Soc. Am. Mem., 364, 143-162, 2002.

Martínez-Catalán, J. R., Arenas, R., Díaz-García, F., and Abati, J.: Variscan accretionary complex of Northwest Iberia: terrain correlation and succession of tectonothermal events, Geology, 25, 1103-1106, 1997.

Matte, P.: La structure de la virgation hercyniennede Galice (Espagne): Extrait des Travaux du Laboratoire de Géologie de la Faculté des Sciences de Grenoble, v. 44, Grenoble, 128 pp., 1968.

Matte, P.: The Variscan collage and orogeny (480-290 Ma) and the tectonic definition of the Armorica microplate: a review, Terra Nova, 13, 122-128, 2001.

Mattinson, J. M.: Zircon U-Pb chemical abrasion ("CA-TIM") method: Combined annealing and multi-step partial dissolution analysis for improved precision and accuracy of zircon ages, Chem. Geol., 220, 47-66, 2005.

Mendia, M. S.: Petrología de la Unidad Eclogítica del Complejo de Cabo Ortegal (NW de España), Lab. Xeol. Laxe, A Coruña, Spain, Serie Nova Terra 16, p. 424, 2000.

Moulas, E., Podladchikov, Y. Y, Aranovich, L.Y., and Kostopoulos, D.: The problem of depth in geology: when pressure does not translate into depth, Petrology, 21, 527-538, 2013. 
Ordóñez-Casado, B., Gebauer, D., Schäfer, H. J., Gil Ibarguchi, J. I., and Peucat, J. J.: A single Devonian subduction event for the HP/HT metamorphism of the Cabo Ortegal complex within the Iberian Massif, Tectonophysics, 332, 359-385, 2001.

Osozawa, S. and Wakabayashi J.: Late stage exhumation of HP metamorphic rocks, progressive localization of strain, and changes in transport direction, Sambagawa belt, Japan, J. Struct. Geol., 75, 1-16, 2015.

Parga-Pondal, I., Vegas, R., and Marcos, A.: Mapa Xeolóxico do Macizo Hespérico, in: Publicacións da Área de Xeoloxía e Minería, Seminario de Estudos Galegos, A Coruña, Spain, 1982.

Pérez-Estaún, A., Martinez-Catalán, J. R., and Bastida, F.: Crustal thickening and deformation sequence in the football to the suture of the Variscan Belt of northwest Spain, Tectonophysics, 191, 243-253, 1991.

Peucat, J. J., Bernard-Griffiths, J., Gil Ibarguchi, J. I., Dallmeyer, R. D., Menot, R. P., Cornichet, J., and Iglesias Ponce de León, M.: Geochemical and geochronological cross section of the deep variscan crust: The Cabo Ortegal high-pressure nappe (NW Spain), in: Terranes in the Variscan Belt of Europe and CircumAtlantic Paleozoic Orogens: Tectonophysics, 177, edited by: Matte, P., Netherlands, Elsevier, 263-292, 1990.

Pin, C., Paquette, J. L., Abalos, B., Santos, F. J., and Gil-Ibarguchi, J. I.: Composite origin of an early Variscan transported suture: Ophilitic units of the Morais Nappe Complex (north Portugal), Tectonics, 25, TC5001, doi:10.1029/2006TC001971, 2006.

Platt, J. P.: Dynamics of orogenic wedges and the uplift of highpressure metamorphic rocks, Geol. Soc. Am. Bull., 97, 10371053, 1986.

Ponce, C., Druguet, E., and Carreras, J.: Development of shear zone-related lozenges in foliated rocks, J. Struct. Geol., 50, 176186, 2013.

Ramsay, J. G.: Folding and Fracturing of Rocks. McGraw-Hill, New York, p. 568, 1967.

Ries, A. C. and Shackleton, R. M.: Catazonal complexes of northwest Spain and North Portugal. Remnants of a Hercynian thrust plate, Nature, 234, 65-68, 1971.

Rosenberg, C. L. and Handy, M. R.: Experimental deformation of partially melted granite revisited: implications for the continental crust, J. Metam. Geol., 23, 19-28, 2005.

Rubio-Ordóñez, A., Valverde-Vaquero, P., Corretge, L.G., Cuesta, A., Gallastegui, G., Fernández-Gonzalez, M., and Gerdes, A.: An Early Ordovician tonalitic-granodioritic belt along the SchistoseGreywacke Domain of the Central Iberian Zone (Iberian Massif, Variscan Belt), Geol. Mag., 149, 927-939, 2012.
Rutter, E. H., Brodie, K. H., and Irving, D. H.: Flow of synthetic, wet, partially molten "granite" under undrained conditions: An experimental study, J. Geophys. Res., 111, B06407, doi:10.1029/2005JB004257, 2006.

Rutter, E. H., Mecklenburgh, J., and Brodie, K. H.: Rock mechanics constraints on mid-crustal low-viscosity flow beneath Tibet, in: Deformation Mechanisms, Rheology and Tectonics: Microstructures, Mechanics and Anisotropy, edited by: Prior, D. J., Rutter, E. H., and Tatham, D. J., Geological Society of London Special Publications, 360, London, 329-336, 2011.

Santos, J. F., Schärer, U., Gil Ibarguchi, J. I., and Girardeau, J.: Genesis of pyroxenite-rich peridotite at Cabo Ortegal (NW Spain): Geochemical and Pb-Sr-Nd isotope data, J. Petrol., 43, 17-43, 2002.

Santos-Zalduegui, J. F., Schäerer, U., Gil Ibarguchi, J. I., and Girardeau, J.: Origin and evolution of the Paleozoic Cabo Ortegal ultramafic-mafic complex (NW Spain); U-Pb, Rb-Sr and $\mathrm{Pb}-\mathrm{Pb}$ isotope data, Chem. Geol., 129, 281-304, 1996.

Shreve, R. L. and Cloos, M.: Dynamics of sediment subduction, melange formation, and prism accretion, J. Geophys. Res., 91, 10229-10245, 1986.

Stacey, J. S. and Kramers, J. D: Approximation of terrestrial lead isotope evolution by a two-stage model, Earth Planet. Sc. Lett., 26, 207-221, 1975.

Valverde, V. P. and Fernández, F. J.: Edad de enfriamiento U/Pb en rutilos del Gneiss de Chimparra (Cabo Ortegal, NO de España), Geogaceta, 20, 475-478, 1996.

van Calsteren, P. W. C., Boelrijk, N. A. I. M., Hebeda, E. H., Priem, H. N. A., den Tex, E., Verdurmen, E. A. T. H., and Verschure, R. H.: Isotopic dating of older elements (including the Cabo Ortegal mafic-ultramafic complex) in the hercynian orogeny of NW Spain: manifestations of a presumed Early Paleozoic Mantleplume, Chem. Geol., 24, 35-36, 1979.

Vogel, D. E.: Petrology of an eclogite- and pyrigarnite-bearing polymetamorphic rock complex at Cabo Ortegal, NW Spain, Leidse Geologische Mededelingen, 40, 121-213, 1967.

Whitney, D. L. and Evans, B. W.: Abbreviations for names of rockforming minerals, Am. Mineral., 95, 185-187, 2010.

Yamasaki, T. and Seno, T.: Double seismic zone and dehydration enbrittlement of the subducting slab, J. Geophys. Res., 108, B42212, doi:10.1029/2002JB001918, 2003. 